\title{
Water and production reallocation in the Spanish agri-food system
}

\author{
Ignacio Cazcarro $^{\text {a,b,c, }}$, Rosa Duarte ${ }^{\text {b,c }}$, Julio Sánchez Chóliz ${ }^{\text {b,c }}$ and \\ Cristina Sarasa ${ }^{\text {b,c }}$ \\ ${ }^{a}$ ARAID (Aragonese Agency for Research and Development), Zaragoza, Spain; \\ ${ }^{\mathrm{b}}$ Department of Economic Analysis, University of Zaragoza, Zaragoza, Spain; \\ ${ }^{\mathrm{c} A g r i f o o d}$ Institute of Aragon (IA2), Zaragoza, Spain
}

\begin{abstract}
MRIO and CGE models have greatly facilitated approaches to environmental and economic problems in recent years. This paper examines regional reallocation criteria intended to reduce water constraints in the Spanish economy. Our goal is to assess the impact of alternative allocation scenarios for regional production on the country's agriculture and agri-food industries, and the associated effects on water resources along the whole length of food supply chains, which display significant asymmetries between regions caused by imbalances in the availability of water resources. We design a CGE model using an MRIO database for Spain. Our scenarios are based on increases in the production of water-intensive crops in regions with more abundant water resources and the development of more sustainable food supply chains between farms and the agri-food industry. Our findings point to a series of policy options that could be applied to ensure successful outcomes in both directions.
\end{abstract}

KEY WORDS: MRIO, CGE models, water re-allocation criteria, food supply chain.

JEL classification: C68, D57, L66, P16, Q10, Q25.

\section{Acknowledgements}

We would like to thank the anonymous reviewers and the editor for their helpful comments. 


\section{INTRODUCTION}

The marked imbalances between water availability and water demand across Spain cause appreciable asymmetries between the country's regions in terms of income, water demand and water resources (see Estrela et al. 2012; Cazcarro et al. 2013). These imbalances affect trade, transport and water consumption. Moreover, certain regions like Murcia and Valencia engage in large-scale production of water-intensive crops despite acute water availability problems (see Table 1), and the production of their agrifood industries accounts for a significant share of regional output. These regions also export much of their agricultural output (53.62\% and $47.16 \%$, respectively), raising a whole host of water-management issues and related challenges for agriculture, worsening aridity conditions and intensifying water scarcity.

Significant differences are also observable between the Spanish regions in terms of the external dependence of local food supply chains. In some regions of northern Spain, notably Galicia, Cantabria, and the Basque Country, the share of agricultural and agrifood industry inputs sourced within the region is considerable; but others, like Murcia and Madrid, tend to import most inputs from elsewhere. For example, local dairy output accounts for only $6.40 \%$ of all purchases in Murcia and $8.98 \%$ in Madrid. The study of short food-supply chains (SFSCs) and the measurement of proximity relations between farming and the agri-food industry recently are getting considerable social and scientific interest. The European Commission has underscored the importance of SFSCs in supporting sustainable development by local producers, helping cut transportation costs, emissions and traffic congestion via local production (EU, 2013).

In this context, the heart of this piece lies in regional differences in water availability, the production of water-intensive goods, and spatial differences in development of sustainable food-supply chains for agri-food industries. This paper, thus, examines ways 
to improve regional food-supply chains that advance agri-food output while also saving water.

We test whether different fiscal policies can contribute to the achievement of structural improvements in regional food supply chains. We do this by tweaking foodsupply chains, that link farmers, agri-food industries and consumers. Could such policies be used to stimulate production of water-intensive crops in regions with more abundant water resources? Could they provide solutions to address the issue of producer and consumer responsibility for water uses? With these questions in mind, we propose alternative production reallocation policies linked to territorial water constraints in Spain.

To achieve our goals, we begin by defining a set of economic and environmental indicators for water scarcity, farm productivity and the dependence of the regional agrifood industry on other regions. These indicators use a 2005 multiregional input-output (MRIO) table for Spain, which is environmentally extended to compute water flows. This allows users to consider the differences among Spain's regions in terms of resource imbalances, as well as consumption and production patterns. Numerous MRIO models have been developed to the contribution of supply chains to overall environmental and economic impacts, see Wiedmann (2009) for a review. Various researchers have analysed the water embodied in Spain's production chains, see, e.g., Dietzenbacher and Velazquez, (2007). In particular, Cazcarro et al. (2013) has developed an MRIO model for Spain that includes interregional flows of water usage.

Given differences among regions, we set out to identify the different types of payments and subsidies that could be deployed to nudge the Spanish economy towards greater water sustainability. These criteria are applied to explore strategies to encourage the production of water-intensive crops in regions with more abundant water resources 
and to stimulate changes in food supply chains by assigning greater responsibility for water consumption to producers and consumers. In this regard, we use water availability indicators to design alternative sets of fiscal measures as a means of establishing new production allocation criteria in relevant sectors.

Next, we develop a computable general equilibrium (CGE) model based on the information of the water-extended 2005 MRIO table for Spain to perform the simulations. Such models are advantageous because they model both supply- and demand-side behaviour, prices and quantities simultaneously and endogenously. That is, CGE models provide a suitably flexible analytical framework for scenario analysis. A number of CGE applications exist that focus upon regional environments, see Bergman (2005) for a general review. A number of studies also discuss water-related CGE models developed in Spain to establish a framework for the analysis of water strategies. (For a full review of CGE models designed to address water issues, see Calzadilla et al., 2017). Philip et al. (2014) assess four alternatives technological solutions that deal with water availability constraints in the province of Huesca (Aragon) in northeastern Spain. Llop and Ponce-Alifonso (2016) model different institutional frameworks that analyse the impacts of agricultural technology developments on the Catalonian economy.

A further methodological objective of our research is combining the MRIO (with regional detail) and CGE approaches to leverage opportunities offered by both. The development of a CGE model based on the water-extended 2005 MRIO table for Spain allows us to address two research issues in the same analysis. CGE models are appropriate for implementing the different types of payments and subsidies postulated in scenario analyses, while MRIO analysis offers a high level of industry and regional disaggregation. By combining the two, we can therefore explore environmental and economic impacts at both the regional and national levels. 
A limited number of studies have probed the power of MRIO modelling by including different technologies and regional economic structures in CGE models. But almost none have addressed the development of sustainable food-supply chains. We identify the regional origin of intermedite inputs and final products within the Spanish economy as a whole. Our work thus extends the single-region approach, and explors the impacts among regions obtained from alternative reallocation scenarios for regional production in agriculture and the agri-food industry, as well as the consequences of those impacts as water-embodied in production.

\section{RESEARCH APPROACH}

We develop a multisector, static, environmentally-extended, multiregional CGE model for Spain. To the best of our knowledge, it is the first of its kind for the country. The core database is a 2005 MRIO table for Spain (Cazcarro et al., 2013). It includes transactions, including water uses, carried out across all 17 Spanish regions as well as the European Union (EU) and the rest of the world (ROW). Our model is novel in that it covers all intraregional, interregional and international transactions in Spain in relation to prior models calibrated for environmental facets (Duarte et al. 2016).

\section{1. Outline of the model}

The model contains 40 sectors. In line with the objective of our study, it focuses upon agriculture and the agri-food industry. The latter is disaggregated into four subsectors - meat, dairy, beverages and tobacco and other food industries. This model uses nested production and utility structures via flexible functional forms. The nested production technology we use is illustrated in Figure $1 .{ }^{1}$ Producers minimize their costs,

\footnotetext{
${ }^{1}$ The nested production function for the intermediate inputs is not included in the case of foreign regions (the rest of the EU and the rest of the world).
} 
assuming Leontief fixed-proportion technology of intermediate inputs and value-added: this is a norm in the literature. The aggregate value-added is a CES function of labour, $L$, and a capital-water composite, $K W$. This splits the main sources of value added, including rents, from water natural resource. The value of the elasticity of substitution for $L$ and $K W$ is slightly lower in agriculture than it is in other sectors. This reflects the relative importance of farmland in agricultural production. As a result, the substitution options for these factors are largely exhausted. At a third level, water and capital substitute for each other via a CES function to produce the $K W$ composite, a device that is widely used in CGE modelling to represent both production and utility. It has the advantage of being well-behaved while yielding reasonable flexibility. It is also consistent with the main assumptions of CGE models (linear homogeneity/homotheticity) while enabling alternative options for the adjustment of demand for the factors of production, which results from changes in their relative prices.

Figure 1. Production function structure

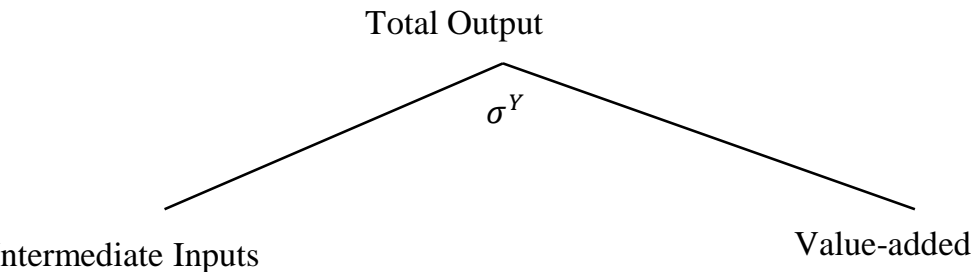

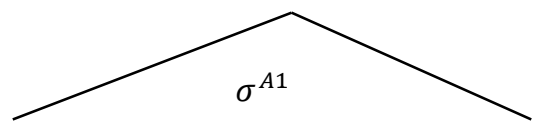

Domestic intermediate

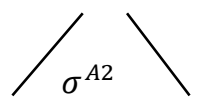

17 Spanish regions
Foreign composite intermediate (EU and ROW)

Source: Own work. Note: $\sigma$ represents elasticities. See Table SI1 of the Supplementary Information for additional information. 
On the bottom left side of the second level of the nested production structure, each intermediate input is produced assuming a CES function using both domestic and foreign goods distinguished by region of origin. We distinguish between domestic inputs from the 17 Spanish regions and foreign inputs from the rest of the EU and the ROW. Thus, each region uses domestically-sourced inputs, inputs from the rest of the Spanish regions, and foreign inputs from the EU and ROW. These functions follow Armington (1969), so that goods are distinguished by region of origin and there are different degrees of substitution between imported and domestic commodities due to price divergences across regions. A high degree of substitution across the Spanish regions is assumed following prior studies (see the notes to Table SI1 of the Supplementary Information, SI).

On the demand side, the four main components of final demand are private consumption, government, investment and exports. Figure 2 reflects the nested demand specification structure of a representative agent in each region defined by a four-stage nested CES utility function. At the top level, the representative decision-maker maximizes a utility function subject to the regional budgetary constraint (total expense cannot exceed income) involved in any consumption-savings decision. Consumers then select the commodity from the whole range of products. The third stage allocates private household expenditure across commodities sourced both domestically and from abroad. This stage determines the degree of substitution that occurs between the domestic composite product and its foreign counterpart. Level four includes substitution across the Spanish regions. Thus, the Armington assumption is also implemented for final products. The government collects taxes and receives transfers from other agents, and spends them on consumption and transfers to other agents. Total public consumption is modelled through a fixed coefficients structure. A regional government is included in 
each region to collect taxes and approve subsidy earmarks (see simulations in the next section). We assume lump-sum transfers between regional governments and the representative agent in each region, and these are endogenously adjusted to ensure the same budget balance as in the baseline.

Figure 2. Nested structure of the representative agent

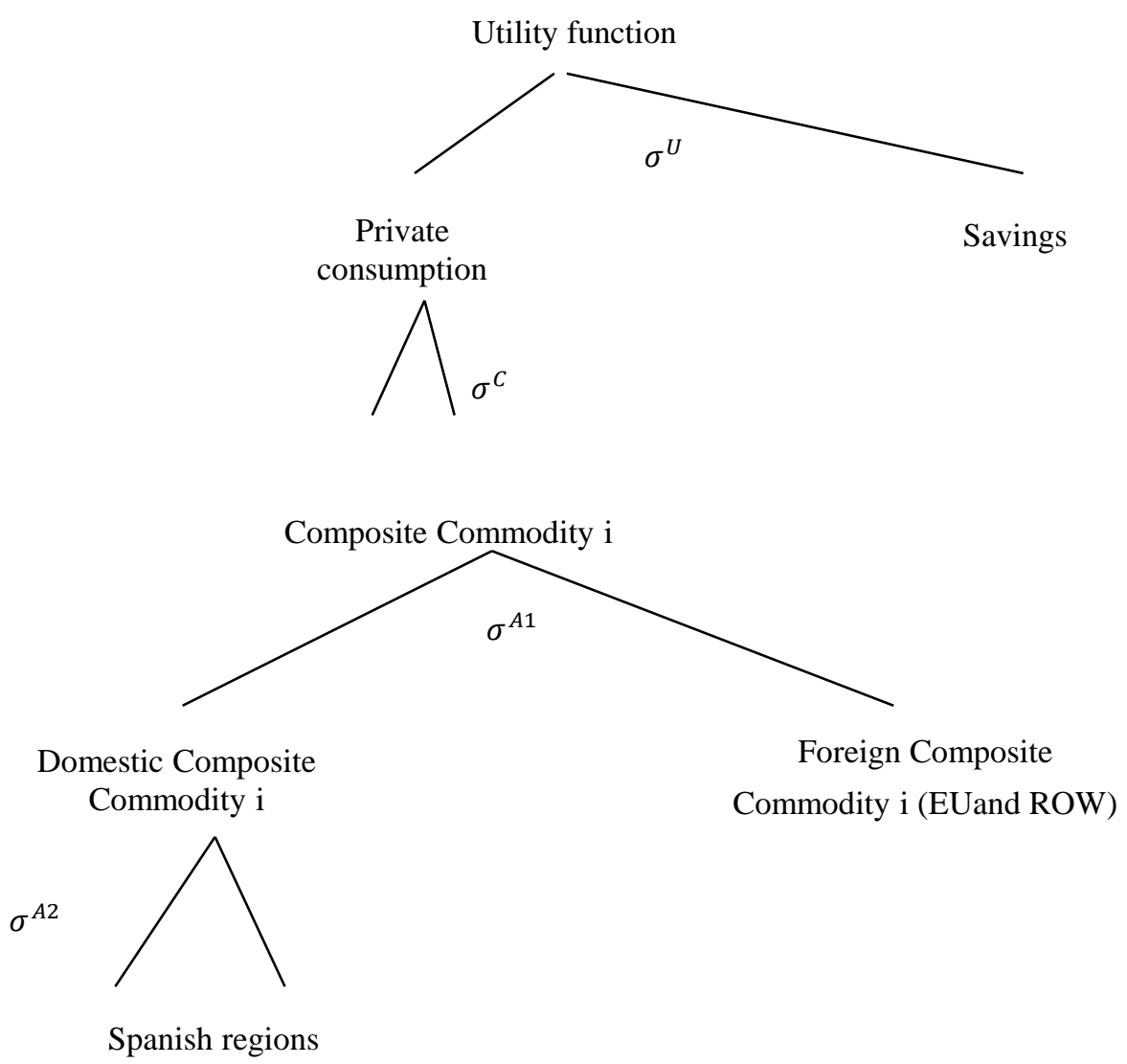

Source: Own work. Note: See Table SI1 of the Supplementary Information for additional information.

Meanwhile, output in each sector is assigned to domestic or foreign demand using a CET function.

Labour, capital and water are assumed to be perfectly mobile across industries, and likewise capital and water across regions. This assumption implies that all sectors in any region face the same market price for capital, in turn implying a long-run interpretation of the simulation results. Labour is mobile across industries but it moves imperfectly across regions, which enables wage differentials across Spanish regions. We model 
labour supply through a CET function, see Figure 3, following Boeters and Savard (2012). This allocates labour in two tiers, comprising the optimal allocation between Spain and other countries in the first stage, and among Spanish regions in the second stage. Transformability of labour is imperfect and strictly driven by unemployment rates. A higher unemployment rate yields a higher elasticity value and, thus, greater mobility of labour across regions. For this reason, our model includes a wage-curve specification following Blanchflower and Oswald (1990). This allows us to consider imperfect competition mechanisms in the labour market. The value of the elasticity of real wages with respect to unemployment included in a wage curve in the model is 0.07, in line with García-Mainar and Montuenga-Gómez (2012).

Figure 3. Nested structure for labour.

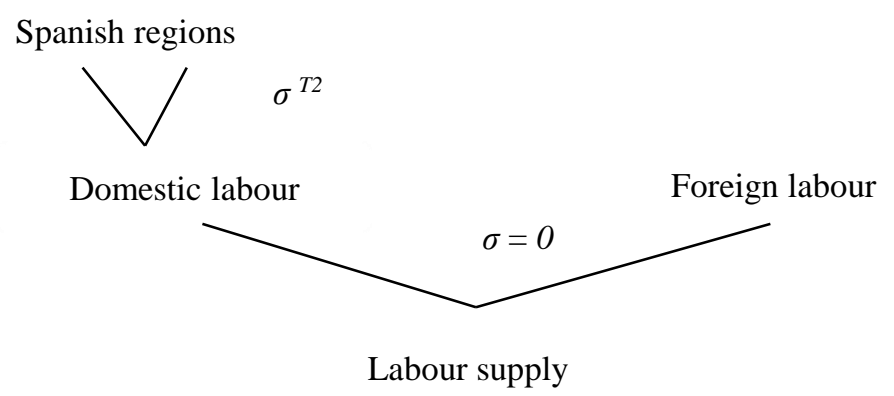

Source: Own work. Note: See Table SI1 of the Supplementary Information for additional information.

We consider two foreign "countries", namely the rest of the EU and ROW. The exchange rate between Spain and the EU is fixed while the trade balance fluctuates, since trade is conducted basically in euros. In contrast, the trade balance between the EU and other countries is constant, so the concordant exchange rate must adjust. The consumer price index (CPI) is used as the numéraire price against which all prices in the model are measured as a measure of purchasing power for the economy as a whole. Finally, we let total investment equals total saving. 


\subsection{Calibration and Data}

A base scenario is a prerequisite for the application of any CGE model. As explained above, the base here is the 2005 MRIO for Spain (Cazcarro et al., 2013) but with water as a factor of production. All prices are equal to unity in the base scenario, with the exception of water. Water prices are obtained from MAPAMA (2005a) as shown in Table SI1 in the SI.

Obtaining industry-specific water data for the 2005 MRIO was a major undertaking. Fortunately, nearly all of Spain's 17 regions had an IO table for 2005 or other nearby year, a coincidence that has not been repeated since. ${ }^{2}$ This suggests that as a multiregional framework, it is probably the best available MRIO that depicts the Spanish economy at any point in recent history. Furthermore, despite its vintage, 2005 represents Spain's economic structure sufficiently well for our purposes; this is because our focus is on water uses by the agri-food system, and the focal industries and relevant economic pressures concerned have remained largely stable over time.

The structural data embedded in the MRIO define some of the model's parameters. Other parameter values were determined exogenously (for example wage-setting functions obtained from the NSI, 2005) based on a review of the literature on CGE models (see Table SI1 of the SI, which includes detailed information about elasticity values). A final set of parameter values is determined through calibration of the model to reproduce the base year dataset. The sensitivity analysis included in the SI compares the results of different domestic commodities substitution elasticities among Spain's regions (parameter $\sigma^{A 2}$ in Figure 1).

\footnotetext{
${ }^{2}$ Note that just six of them have updated their frameworks to 2010 and even less to other years. Neither is there any updated interregional trade data and sector specific water data to accommodate an updated MRIO.
} 


\section{3. Extending the model to water uses}

Given an IOT, we can define a Leontief model starting from a matrix of technical coefficients $\mathbf{A}$, a production vector $\mathbf{x}$, and a final demand vector $\mathbf{y}$. The equation that defines this type of model is: $\mathbf{x}=\mathbf{A} \mathbf{x}+\mathbf{y} \Leftrightarrow \mathbf{x}=(\mathbf{I}-\mathbf{A})^{-\mathbf{1}} \mathbf{y}$

where $(\mathbf{I}-\mathbf{A})^{-1}$ is the inverse of Leontief.

In this framework, if we have a vector $\mathbf{c}=\left(c_{j}\right)$ of coefficients of direct water use ${ }^{3}$, we can define the direct water use associated with the production of a good vector $\mathbf{x}=\left(x_{j}\right)$ as $\mathbf{c}^{\prime} \mathbf{x}$, since $c_{j}$ represents the amount of water used in the production per unit of good $x_{j}$. Similarly, we can define the water value (embodied water or virtual water) of a vector of final demand $\mathbf{y}=\left(y_{j}\right)$ as

$$
W(\mathbf{y})=\mathbf{c}^{\prime}(\mathbf{I}-\mathbf{A})^{-1} \mathbf{y}
$$

where $W(\mathbf{y})$ is the water required directly and indirectly to produce $\mathbf{y}$.

Using this approach, we establish a baseline situation to obtain direct water uses and estimates of the virtual water consumed in any regional production, as well as the virtual or embodied water contained in any regional imports or exports. We then estimate changes in water consumption and (direct or embodied) water flows in terms of differences between the initial and final situations obtained as the simulation is performed in the MRIO used.

Additionally, we define blue-water scarcity indices for each Spanish region. Each regional index is defined as direct (blue in Figure 4a, blue and green in Figure 4b) water

\footnotetext{
3 The term "use" is employed generically here. There is an extensive literature dealing with the concepts and differences of water use types, especially consumptive use and non-consumptive uses, impacts, etc. (e.g. related to the ISO 14046 water footprint definition, in LCA water consumption literature, etc., see ISO_14046, 2014). We follow the approach of the water footprint literature (Hoekstra et al., 2011) and compute both the (direct) blue and green water consumptive use. Blue water is defined as fresh surface and groundwater. Green water is the rainwater stored in the ground and absorbed by crops. Blue and green water have different environmental effects and policy implications, and they can be used together or independently in studies of water and distribution.
} 
use divided by renewable water resources (run-off) ${ }^{4}$ (analogously to long-lasting proposed measures such as the Water Exploitation Index, Alcamo et al., 2000). In our estimates, water consumption is obtained for agriculture from Mekonnen and Hoekstra (2011). We generated our own estimates for other sectors mainly using NSI (2010, 2014 , 2016). We obtained those for run-off, natural and potential water availability (as an alternative measure) via MAPAMA (2015a, b, c), SIMPA (2010), MSSI (2015), IGME (2015) and FAO (2019). Table SI2 of the SI reports details regarding use and availability of water data required to obtain the indices.

We also define another similar scarcity index based on the embodied water with respect to water resources. We then split these indices into a consumption scarcity index and an exports scarcity index, as shown in Table 1 . They were estimated as the ratios of blue water embodied in each region's consumption and exports to natural water availability (run-off).

Additionally, we performed a sensitivity analysis to test other water scarcity indexes, see Table SI11 in the SI. First, we consider embodied blue and green water consumption and exports; and second, we define the index with respect to potential water availability (considering water transfers, reutilization and desalination capabilities and environmental reserves) instead of natural run-off. We also considered alternative scarcity indicators but modelling and comparing them were challenging. ${ }^{5}$

\footnotetext{
${ }^{4}$ The method used computes the provincial run-off, which is then aggregated at the level of the Autonomous Communities (i.e. the political regions of Spain). We begin with raster data $(1 \mathrm{~km}$ by $1 \mathrm{~km})$ on precipitation, potential and real evapotranspiration, and ultimately run-off raster data in Spain (SIMPA, 2010). This we aggregate to the provincial level using ArcGIS. We used supplementary data (FAO, 2019 and MAPAMA 2015b, 2015c) to check the total run-off values obtained against alternative measures of water availability.

${ }^{5}$ Working with relative indicators in the modelling involves many challenges when being accounted along the supply chains (working with a ratio such as water scarcity ratio, which is again divided by the output to obtain coefficients). An alternative is an approach like Lenzen et al. (2013), which is based on applying initially a pressure ratio (based on consumption per availability) and working with absolute figures of consumption $\left(\mathrm{m}^{3}\right)$. We also explored water stress indices (e.g. Pfister et al., 2009; Quinteiro et al., 2018) that pose a challenge in modelling since it means working with actual consumption as transformed by so-called "characterization factors".
} 


\subsection{Measuring the external dependence of supply chains}

One of our objectives is to promote the development of sustainable food-supply chains. We did so by assessing the external dependence of the production chains for agri-food goods. Input-output tables include several production chains with varying lengths and importances. Rather than examining any particular chain, however, we look at the group of all chains that include the same source sector and that have the same final destination sector. The simplest way to capture all these is to use the Leontief inverse matrix, $(\mathbf{I}-\mathbf{A})^{-1}=\left\{\alpha_{i_{r} j_{s}}\right\}$, since $\alpha_{i_{r}, j_{s}}$ are the goods produced in sector $i_{r}$ from region $r$ that are used directly or indirectly per unit of final good in sector $j_{s}$ from s. Hence, one way of measuring the external dependence of the chains associated with the final good $j_{S}$ is to use the backward linkage of sector $j_{S}$, which gives us the inputs directly or indirectly consumed to obtain each unit of good $j_{s}$. If we want to know whether a productive sector $j_{s}$ in a region $s$ depends to a greater or lesser degree on the production of other regions, we can measure this roughly using the $\operatorname{ratio}^{\sum i_{r} \alpha_{i_{r, j_{s}}}} / \sum i_{r, r=s} \alpha_{i_{r, j_{s}}}$

Let us note that if sector $j_{s}$ purchased its inputs only within region $s$, then the measure would be 1 , and if it made no purchases in the region the measure would be $\infty$. In other words, the index will be higher, the greater the dependence of sector $j_{s}$ in a given region $s$ on any other region and, conversely, it will be lower, the smaller the share of inputs contributed directly or indirectly by other regions to the total inputs used by sector $j_{S}$.

\section{SCENARIOS}

The three alternative scenarios described below are designed to address our principal objectives. They provide incentives to encourage production of water-intensive products 
in regions with greater water availability, enhance farm productivity and reduce the dependence of the regional agri-food industry on other regions. The baseline scenario is that described by the 2005 MRIO for Spain that includes water data; it is the benchmark against which different policy scenarios are contrasted.

\section{Baseline scenario}

Let us begin by analysing the blue-water scarcity indexes for each Spanish region presented in Table 1. This should enable a clear understanding of water dependence conditions in Spain's economy. Results of water scarcity are displayed in Figure 4, in which map $a$ shows direct blue-water scarcity and map $b$ blue- and green-water consumption in relation to water availability.

Table 1. \% Level of blue water scarcity (embodied water with respect to water resources) in the Spanish regions per 2005 MRIO

\begin{tabular}{lccclccc}
\hline Region & Consumption & Export & Total & Region & Consumption Export & Total \\
\hline Andalusia & 28.60 & 19.41 & 48.01 & Galicia & 0.90 & 0.35 & 1.25 \\
Aragon & 30.53 & 23.96 & 54.49 & La Rioja & 12.67 & 9.16 & 21.83 \\
$\begin{array}{l}\text { Castile-La } \\
\text { Mancha }\end{array}$ & 18.95 & 14.91 & 33.86 & Madrid & 112.39 & 45.87 & 158.26 \\
Asturias & 1.69 & 0.90 & 2.59 & Navarre & 11.87 & 10.46 & 22.33 \\
Balearic Islands & 33.16 & 10.71 & 43.86 & $\begin{array}{l}\text { Basque } \\
\text { Country }\end{array}$ & 5.31 & 5.15 & 10.47 \\
Canary Islands & 72.33 & 15.16 & 87.49 & Extremadura & 16.90 & 18.31 & 35.21 \\
Cantabria & 3.33 & 2.22 & 5.54 & $\begin{array}{l}\text { Murcia, Ceuta } \\
\text { and Melilla }\end{array}$ & 130.56 & 150.94 & 281.50 \\
Castile and & 12.64 & 8.85 & 21.49 & Valencia & 54.07 & 48.26 & 102.33 \\
Leon & & & & & & & \\
Catalonia & 34.80 & 20.61 & 55.41 & Total & $\mathbf{1 5 . 9 5}$ & $\mathbf{1 1 . 9 8}$ & $\mathbf{2 7 . 9 3}$ \\
\hline
\end{tabular}

Source: Own work. 
Figure 4. Map of direct blue water scarcity (a), and direct blue and green water scarcity (b) in Spanish regions

a)

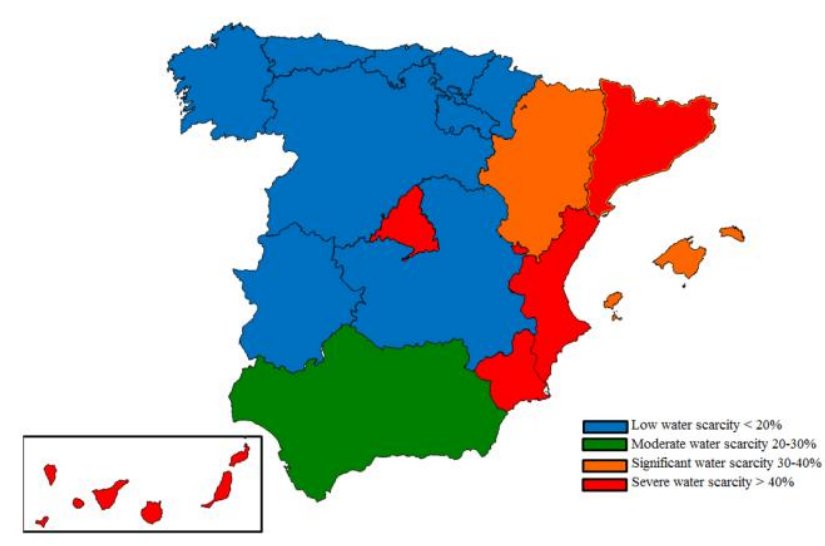

b)

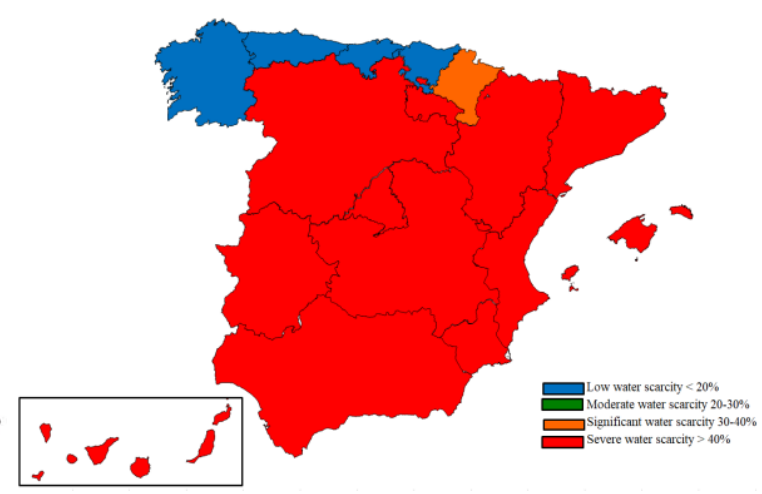

Source: Own elaboration from Mekonnen and Hoekstra (2011), NSI (2010, 2014, 2016), MAPAMA (2015a), MSSI (2015), IGME (2015), FAO (2019).

As may be observed, Table 1 reveals signs of acute water scarcity in the Murcia ${ }^{6}$ and Madrid regions, with eye-catching figures of $281.5 \%$ and $158.26 \%$, respectively, estimated for their domestic and foreign blue-water demand in relation to available water resources. Serious water scarcity in relation to consumption is also evident in the Canary Islands and the Valencia region $(87.49 \%$ and $102.33 \%$, respectively). The lowest figures, in all cases less than $11 \%$, not surprisingly are found in the Atlantic regions of Galicia, Asturias, Cantabria and the Basque Country in northern Spain.

Focusing on consumption to evaluate the type of "overshoot" (if any) found in each region, both Murcia and Madrid need much more water than their currently available resources to meet local regional demand. A key reason for Murcia's very high level of water scarcity is its top position as an exporter. That is, due to its outward shipment of water-intensive goods, its water demand exceeds its local water resources. Autonomous

\footnotetext{
${ }^{6}$ For the purposes of this study, the Murcia region has been grouped with the autonomous North-African exclaves of Ceuta and Melilla. Murcia itself accounts for $2.6 \%$ of Spain's GDP, Ceuta for $0.15 \%$ and Melilla for $0.14 \%$. In other words, the "mainland" Murcia represents $90 \%$ of the "grouped" region. Thus, it is reasonable to abbreviate the label of the discussion results here simply as "Murcia".
} 
Communities of Valencia and Madrid appear to run into similar problems since both appear to use more than $45 \%$ of their own water resources in the goods that they ship out of the immediate region. These indicators thus reveal how water scarcity is directly and indirectly affected by patterns of regional consumption, trade, and production.

A second important property of the baseline scenario is the set of apparent regional water productivities in agriculture (sometimes called simply "productivities"), which are calculated here as the agricultural output of each region divided by direct (blue and green) water use. Green water is included here because some regions benefit from rainfall stored as groundwater. We also estimate the dependence indices defined above to assess purchases of domestic agricultural inputs made by agri-food industries within each region. Table 2 shows both results for each region.

The most productive region in terms of (apparent) water consumption in agriculture is Murcia (plus Ceuta and Melilla), followed by Cantabria, the Basque Country, Galicia, and Asturias. Apparent water productivity in Murcia is due both to the high value of its agricultural output and to its limited water resources, mainly composed of blue water. The other top regions in terms of apparent water productivity are the small Autonomous Communities of northern Spain, where water consumption is low compared to the level of agricultural output. This is due mainly to topography and climate conditions, which favour certain kinds of farming. For example, Galicia's agricultural output is large, but it uses small amounts of blue water. The lowest levels of apparent water productivity are found in the regions of Castile-La Mancha, Castile and Leon, Aragon and Andalusia, all of which are have more than their "fair share" of the nation's agriculture production and equally high levels of blue-water consumption. 
Table 2. Productivity index and \% domestic regional input purchase in 2005

\begin{tabular}{|c|c|c|c|c|c|}
\hline \multirow[b]{2}{*}{ Region } & \multirow{2}{*}{$\begin{array}{l}\text { Agriculture } \\
\text { productivity } \\
\text { index }\left(€ / \mathbf{m}^{3}\right)\end{array}$} & \multicolumn{4}{|c|}{ Domestic regional input purchase index } \\
\hline & & $\begin{array}{c}\text { Meat } \\
\text { industry }\end{array}$ & $\begin{array}{c}\text { Dairy } \\
\text { industries }\end{array}$ & $\begin{array}{l}\text { Other food } \\
\text { industry }\end{array}$ & $\begin{array}{l}\text { Beverages } \\
\text { and tobacco }\end{array}$ \\
\hline Andalusia & 0.73 & 1.10 & 1.07 & 1.14 & 1.15 \\
\hline Aragon & 0.55 & 1.28 & 1.05 & 1.29 & 1.20 \\
\hline Castile-La Mancha & 0.42 & 1.14 & 1.20 & 1.17 & 1.14 \\
\hline Asturias & 1.55 & 1.24 & 1.16 & 1.31 & 1.13 \\
\hline Balearic Islands & 0.76 & 1.18 & 1.04 & 1.56 & 1.34 \\
\hline Canary Islands & 1.54 & 1.19 & 1.18 & 1.14 & 1.05 \\
\hline Cantabria & 2.84 & 1.12 & 1.19 & 1.18 & 1.22 \\
\hline Castile and Leon & 0.54 & 1.11 & 1.12 & 1.2 & 1.11 \\
\hline Catalonia & 1.08 & 1.31 & 1.11 & 1.46 & 1.16 \\
\hline Galicia & 1.68 & 1.07 & 1.1 & 1.33 & 1.14 \\
\hline La Rioja & 0.93 & 1.22 & 1.22 & 1.27 & 1.16 \\
\hline Madrid & 0.83 & 1.65 & 1.53 & 1.46 & 1.20 \\
\hline Navarre & 0.81 & 1.24 & 1.40 & 1.41 & 1.18 \\
\hline Basque Country & 1.82 & 1.11 & 1.07 & 1.31 & 1.28 \\
\hline Extremadura & 0.92 & 1.26 & 1.29 & 1.36 & 1.24 \\
\hline Murcia, Ceuta and Melilla & 3.21 & 1.72 & 1.72 & 1.78 & 1.57 \\
\hline Valencia & 1.40 & 1.32 & 1.22 & 1.35 & 1.30 \\
\hline Average & 1.27 & 1.25 & 1.22 & 1.34 & 1.21 \\
\hline Total Spain & 0.82 & 1.05 & 1.05 & 1.14 & 1.08 \\
\hline
\end{tabular}

Finally, we may observe that dependence indexes (i.e. purchases of domestic regional inputs) varies with the region's specific agri-food focus. In general, however, northern regions, like Galicia and the Basque Country, and central regions (Castile and Leon, Castile-La Mancha and Aragon) use more of their agricultural inputs locally (i.e. within the region itself), so their dependence-index values are correspondingly lower. 


\section{Proposed scenarios}

The indicators defined above can be used to evaluate three scenarios associated with alternative sets of fiscal measures. Specifically, we examine the potential production reallocation between sectors and regions that would be induced by certain fiscal measures. We assume that the implementation of these measures would involve a total outlay of $€ 10$ billion, ${ }^{7}$ which is collected as taxes and awarded as subsidies to farmers and the agri-food industry.

Specifically, we propose taxes that are based on the existing water-scarcity indices that are associated with total demand (consumption plus exports) presented in Table 1. Their design is the result of multiplying direct regional water consumption by the ratio of the regional water scarcity index to the national water scarcity level, assuming that the total national tax take will be $€ 10$ billion. These taxes are collected from different agents (producers or consumers) in the different scenarios.

Scenario 1. Taxes are only paid by producers in the agriculture and agri-food sectors as a tax on production. They are designed to reduce water consumption in the regions with greater scarcity by raising costs in those regions and, thereby, lowering demand for production from relatively water-scarce regions.

Scenario 2. Taxes are levied on commodities at the retail level and, hence, paid by consumers. The composite household in each region is expected, in this scenario, to adjust its consumption away from water-scarce goods, which makes substitution effects key.

Scenario 3. This scenario applies both a producer and consumer tax, such that half of the revenues from the tax are collected from farmers and agri-food producers as taxes

\footnotetext{
${ }^{7}$ This amount is less than $10 \%$ of total farm output, which was the actual amount of subsidies awarded in Spain in 2005 (MAPAMA, 2005b). We assume the same amount for all Scenarios for resasons of comparability.
} 
on production and the other half is collected from composite households as a tax on commodities they consume.

Subsidies are equal in all scenarios. See Table SI3 where they are shown together with the tax rates. The subsidies are aligned with indicators as shown in Table 2, which ensures comparability across scenarios. The tax is earmarked for subsidies to farming and four agri-food sectors (Meat Industry, Dairy Industry, Beverages and Tobacco and Other Food Industries), each of which receives $€ 2$ billion. These amounts are included as production subsidies in the agriculture and agri-food industry production functions. But no farm subsidies are awarded to regions with acute water scarcity. In the rest of the regions, the $€ 2$ billion subsidy depends on regional water productivity and is awarded in proportion to both regional water consumption and the productivity index. In other words, more efficient water use qualifies these regions (i.e. those not affected by severe water scarcity) for a larger subsidy per unit of water consumption.

In the case of the agri-food sectors, the regional share of the total $€ 2$ billion subsidy assigned to each industry is proportional to the amount of local inputs purchased directly. Hence, a region receives a relatively larger subsidy if its agri-food industries buy relatively more inputs from local farmers and agri-food producers.

\section{RESULTS}

\section{Changes in regional production values}

Table 3 provides an overview of output in agriculture and the agri-food industries by region by scenario. Additional changes by region are reported in detail in Tables SI4, SI5, SI6, SI7 and SI8 of the SI. Tables SI9 and SI10 of the SI present a sensitivity analysis of Table 3 results to the elasticities of substitution of domestic commodities among Spanish regions. Table SI1 1 of the SI shows how results change via application of a different set of water scarcity indexes. 
In general, subsidies boost the value of production in farming and agri-food industries and offset the reduction caused by tax payments (see Table 3 ). ${ }^{8}$ These values differ by $5.1 \%$ in Scenario 1, $14.2 \%$ in Scenario 2, and $8.8 \%$ in the mixed Scenario 3 versus the baseline. This suggests that supply-side subsidies more than offset production reductions associated with taxation; bear in mind that the total value of subsidies is necessarily equal to the tax revenues collected.

Interestingly, both increases and reductions in regional agri-food production are observable where taxes are paid by producers (Scenario 1), and there is a large reallocation between regional production levels. In contrast, when consumers pay the tax (Scenario 2), the value of production does not decrease, as observed in Table 3. Moreover, the value of agricultural and agri-food production increases in all regions, as does the concordant physical output (see Table SI4 of the SI). Thus, when consumption is taxed, water availability concerns are not fully transferred to food producers. They increase production even in regions subject to acute water scarcity, e.g., Murcia, Valencia, Madrid and the Canary Islands. Finally, Table 3 shows Scenario 3 results are a blend of outcomes arising from Scenarios 1 and 2.

\footnotetext{
${ }^{8}$ Higher values for sectoral and regional production are associated with lower physical outputs (production value/price) and price rises. Table SI4 of the SI shows the changes in physical output.
} 
Table 3. Regional and sectoral production results (\% change with respect to the baseline scenario)

\begin{tabular}{|c|c|c|c|c|c|c|c|c|c|c|c|c|c|c|c|c|c|c|c|c|c|}
\hline & \multicolumn{7}{|c|}{$\begin{array}{c}\text { Scenario } 1 \\
\text { (Taxes on production) }\end{array}$} & \multicolumn{7}{|c|}{$\begin{array}{c}\text { Scenario } 2 \\
\text { (Taxes on consumption) }\end{array}$} & \multicolumn{6}{|c|}{$\begin{array}{c}\text { Scenario } 3 \text { (Taxes on production and } \\
\text { consumption) }\end{array}$} & \multirow[b]{2}{*}{ 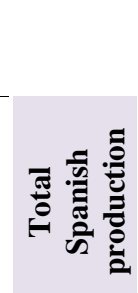 } \\
\hline & 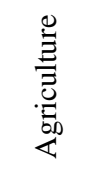 & 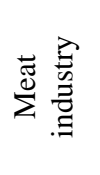 & 坣苛 & 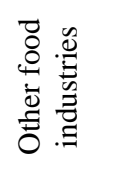 & 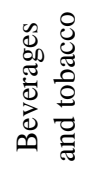 & 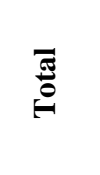 & 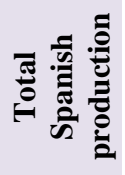 & 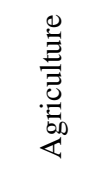 & 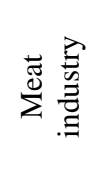 & 坣莺 & 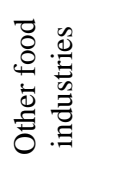 & 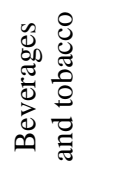 & हैं & 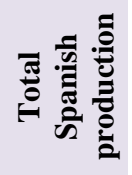 & 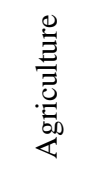 & 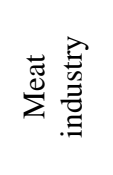 & : & 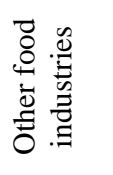 & 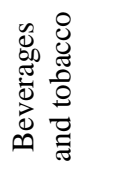 & 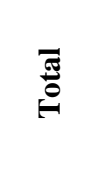 & \\
\hline Anda & -4.01 & -5.00 & 27.07 & -1.05 & -9.48 & -3.12 & -1.11 & 7.10 & 11.99 & 25.52 & 13.79 & 4.06 & 9.61 & 0.27 & 1.53 & 2.59 & 23.62 & 5.94 & -2.92 & 2.91 & -0.43 \\
\hline Aragon & 1.99 & 10.99 & 22.36 & 26.23 & 412.44 & 24.35 & 2.14 & 9.85 & 22.42 & 22.95 & 32.15 & 242.98 & 25.50 & 2.23 & 5.60 & 15.10 & 20.28 & 27.97 & 306.49 & 23.26 & 2.05 \\
\hline Castile-La Mancha & -1.58 & -4.44 & 3.94 & 15.98 & -2.50 & 1.11 & -0.32 & 8.22 & 12.36 & 12.91 & 25.25 & 8.02 & 11.94 & 1.21 & 3.18 & 3.03 & 7.22 & 19.69 & 2.20 & 5.93 & 0.38 \\
\hline Asturias & 143.16 & 152.36 & 9.47 & 32.48 & -2.56 & 56.97 & 3.48 & 74.54 & 114.59 & 15.93 & 36.35 & 7.98 & 42.30 & 2.38 & 101.29 & 125.68 & 11.14 & 33.01 & 2.16 & 46.23 & 2.71 \\
\hline Balearic Islands & 77.26 & 58.40 & 81.80 & 7.58 & 76.64 & 57.51 & 1.38 & 44.35 & 53.33 & 55.33 & 19.59 & 52.83 & 42.01 & 0.87 & 56.63 & 52.18 & 62.43 & 12.90 & 60.24 & 46.32 & 1.02 \\
\hline Canary Islands & -7.68 & 41.83 & -1.78 & 6.59 & 4.62 & 1.06 & -0.89 & 5.42 & 42.53 & 9.79 & 18.93 & 12.05 & 11.86 & -0.51 & -0.95 & 39.22 & 3.16 & 12.11 & 7.43 & 5.94 & -0.69 \\
\hline Cantabria & 285.44 & 105.92 & 278.18 & 40.14 & 146.49 & 159.43 & 9.30 & 139.75 & 84.31 & 162.33 & 41.51 & 92.38 & 93.90 & 5.29 & 197.74 & 89.36 & 201.69 & 39.20 & 111.46 & 118.24 & 6.81 \\
\hline Castile and Leon & -1.76 & -10.94 & 22.37 & 2.31 & 15.18 & 0.49 & -0.59 & 8.13 & 8.12 & 22.95 & 16.05 & 18.03 & 12.17 & 1.15 & 3.06 & -2.06 & 20.28 & 8.65 & 15.17 & 5.68 & 0.22 \\
\hline Catalonia & 6.49 & -18.90 & 10.67 & -13.89 & -10.46 & -10.17 & -1.33 & 11.91 & 2.93 & 16.58 & 5.15 & 3.51 & 5.99 & -0.25 & 8.65 & -8.29 & 11.99 & -4.43 & -3.63 & -2.40 & -0.78 \\
\hline Galicia & 16.78 & 32.42 & 38.06 & -5.04 & 35.21 & 13.58 & 0.68 & 16.63 & 36.39 & 31.50 & 11.10 & 29.37 & 18.75 & 1.25 & 15.63 & 31.86 & 31.41 & 2.71 & 29.86 & 14.90 & 0.88 \\
\hline La Rioja & 71.76 & 32.24 & 63.44 & -1.29 & 11.65 & 25.56 & 3.68 & 41.83 & 36.27 & 45.33 & 13.63 & 16.03 & 23.66 & 3.39 & 52.90 & 31.72 & 49.41 & 5.75 & 12.58 & 22.72 & 3.25 \\
\hline Madrid & -7.68 & -19.72 & -9.79 & -15.01 & 17.55 & -8.67 & -1.00 & 5.42 & 2.40 & 5.43 & 4.39 & 19.37 & 7.04 & -1.00 & -0.95 & -8.93 & -2.52 & -5.33 & 16.91 & -1.22 & -0.99 \\
\hline Navarre & 41.89 & 52.06 & 152.66 & 1.73 & 70.99 & 30.65 & 2.80 & 28.14 & 49.20 & 93.94 & 15.66 & 49.63 & 29.30 & 2.66 & 32.65 & 47.22 & 112.68 & 8.18 & 56.10 & 27.91 & 2.55 \\
\hline Basque Country & 137.77 & 78.89 & 117.16 & -2.37 & 6.24 & 38.66 & 0.81 & 72.08 & 66.69 & 74.60 & 12.90 & 12.97 & 31.35 & 0.45 & 97.64 & 68.22 & 87.50 & 4.87 & 8.61 & 32.36 & 0.58 \\
\hline Extremadura & 7.19 & 38.84 & 65.89 & 6.95 & 1.19 & 9.54 & 0.96 & 12.24 & 40.58 & 46.67 & 19.17 & 10.11 & 16.43 & 1.95 & 9.13 & 36.88 & 51.15 & 12.40 & 4.91 & 12.12 & 1.35 \\
\hline Murcia & -7.68 & 3.23 & 9.83 & -0.88 & -5.83 & -4.95 & -1.66 & 5.42 & 17.36 & 16.12 & 13.90 & 6.13 & 8.27 & 0.90 & -0.95 & 9.03 & 11.39 & 6.08 & -0.24 & 1.52 & -0.38 \\
\hline Valencia & -7.68 & 13.84 & 3.06 & -11.15 & 7.08 & -3.67 & -0.87 & 5.42 & 24.28 & 12.43 & 6.99 & 13.44 & 9.59 & 0.20 & -0.95 & 17.32 & 6.59 & -2.22 & 9.23 & 2.56 & -0.33 \\
\hline Total for Spain & 9.48 & -1.05 & 23.10 & -2.32 & 7.72 & 5.14 & -0.25 & 12.04 & 13.42 & 5.95 & 8.90 & 11.02 & 14.19 & 0.37 & 10.67 & 5.68 & 20.80 & 4.91 & 9.70 & 8.82 & 0.02 \\
\hline
\end{tabular}


In Scenario 1 agricultural output falls in regions with serious water scarcity problems (Murcia, Valencia, Madrid and the Canary Islands). It balances large increases in production in the regions of northern Spain that have better water availability conditions. e.g., Cantabria, Asturias and the Basque Country. These results emerge because the former regions receive no subsidies while the latter in net both receive subsidies and pay fewer taxes. The impacts on production prices are shown in Table SI5 in the SI and are linked to tax rates shown in Table SI3 based on the water scarcity index. The increase in prices relative to the CPI in the regions of northern Spain are lower than are the net rises in other regions, reflecting an improvement in price competitiveness that boosts sales. Specifically, the four regions of northern Spain that have the most water available raised their Agriculture production prices, ranging between $1.2 \%$ (Galicia) and 8.0\% (Cantabria). On the contrary, regions like Murcia, Valencia, Madrid and the Canary Islands, where water availability is severely limited, very steep price rises, ranging from $10.3 \%$ to $78.3 \%$, resulting a loss of competitiveness.

Taxes on consumption (Scenario 2) cause small decreases in agricultural production prices in relation to the CPI in all regions except Cantabria, Asturias and Aragon. This contrasts starkly against the large increases observed in Scenario 1. These small agricultural price reductions result from lower consumption, which in aggregate encourage producers to cut prices (see Table SI5). But in this scenario, we also observe some reallocation of production towards regions in which water is in greater abundance. This yields large, subsidy-induced increases in output in regions like Cantabria, Asturias, and the Basque Country.

Reallocations in the distribution of total agricultural production within Spain's economy increases the total value of agricultural output by $9.5 \%$ in Scenario 1 and by $12.0 \%$ in Scenario 2. Note, the results are positive and substantial in both cases.

In the case of agri-food industries, the three largest increases in production values are found in the same regions in all scenarios; although the scenarios yield different ranges. In the 
case of the Meat Industry, Asturias, Cantabria and the Basque Country enjoy increases, while Madrid, Catalonia, Castile and Leon (the last two are the largest meat producing regions in the base year) suffer mild decreases (see Table SI7). Following agricultures lead, aggregate output contracts in some regions in Scenario 1, but all regions enjoys its rise in Scenario 2. The large increases in the Balearic Islands in Scenario 2 are in part due to the archipelago's Mediterranean location. The other small regions, including Cantabria, Navarre and the Basque Country present significant increases in Dairy production, again via the subsidies received. But Dairy production shrinks in Madrid and the Canary Islands in Scenario 1 but it increases for them slightly in Scenario 2. The largest rises in the output of Other Food Industries are found in Cantabria, Asturias and Aragon. The largest increases in Beverages and Tobacco occur in Aragon and Cantabria - regions that use the greatest share of their own agricultural and agri-food industry production, as a result of which they receive proportionally more subsidies.

The effects of the different scenarios on agri-food prices pattern after those for agriculture only (see Table SI5). Scenario 1 reveals sharp spikes in prices in regions with severe water scarcity, with price rises ranging from some $15 \%$ (Valencia) to $75 \%$ (Murcia). The price rises in turn lead to declines in demand for output from these region's (see Tables 3 and SI4 in the SI). These substantial price increases arise both from higher taxes applied to and lower subsidies received by arid regions. Meanwhile, regions that receive subsidies received offset tax rises, resulting in a ramp up of production, e.g., Basque Country, La Rioja and Galicia. But when taxes are applied to consumption (Scenario 2), prices fall in all regions except Cantabria, Asturias, La Rioja, Aragon and Navarre (all in northern Spain). Moreover, the price drop in agri-businesses is steeper in regions that have a higher rate of taxation due to water-scarcity premia (Valencian Community, Murcia, Madrid, Catalonia and the Canary Islands). This is due basically to falling consumption in the water-scarce regions themselves, 
as observed in the physical quantity of agriculture production (see Table SI6); as a result, producers have no option but to cut prices.

The sensitivity analyses (Tables SI9 and SI10) test the effects of higher elasticities for domestic commodities among the Spanish regions. Such elasticities allow greater flexibility to reallocate the purchase of inputs since producers can now more easily switch among suppliers across different regions. Findings for Scenario 1 yield even larger increases in farm and agrifood industry production in regions with better water availability conditions in all scenarios, with concomitant output declines more steeply in regions with serious scarcity problems. In this light, strengthening substitution effects by increasing access to available domestically produced intermediate commodities from other Spanish regions could lead to environmental improvements even further by reducing pressures in regions with scarce resources while maintaining overall agri-food output and the associated revenues.

\section{Broader changes}

Table 4 presents the broader macroeconomic outcomes for Spain as a whole, and Table 5 shows regional results. Examination of macroeconomic impacts shows that a small drop in total production should be expected when taxes are paid by producers (Scenario 1). This is because the associated reallocation causes declines in output from regions that produce the most agri-food and agricultural commodities. When taxes are paid by consumers (Scenario 2), however, total output should be expected to pick up, largely driven rises in the value of agrifood and farm output in all regions, despite the industries' relatively small representation within the overall economy. The blend of policies in Scenario 3 results in a small gain of $0.02 \%$ in aggregate output after reallocation across regions. In all scenarios, private consumption falls as a result of declining available income due to tax payments. 
Table 4. Macroeconomic results

(\% change with respect to the baseline scenario)

\begin{tabular}{lccc}
\hline & $\begin{array}{c}\text { Scenario 1: } \\
\text { Taxes on } \\
\text { production }\end{array}$ & $\begin{array}{c}\text { Scenario 2: } \\
\text { Taxes on } \\
\text { consumption }\end{array}$ & $\begin{array}{c}\text { Scenario 3: } \\
\text { Mixed } \\
\text { payment }\end{array}$ \\
\hline Total production & -0.252 & 0.375 & 0.024 \\
Total Private Consumption & -2.399 & -2.267 & -2.113 \\
Exports & -2.428 & 1.664 & -0.062 \\
Imports & 0.055 & 0.043 & 0.043 \\
CPI & 0.000 & 0.000 & 0.000 \\
\hline
\end{tabular}

Our analysis of trade results reveals a fall in total exports when taxes are paid by producers (Scenario 1) and an increase in line with expectations when taxes are paid by consumers (Scenario 2). This is due to the effect on production prices shown in Table SI5. The higher prices produced by Scenario 1 affect the competitiveness of exports. Meanwhile, imports rise in both scenarios driven by higher domestic prices and, as always, the results of Scenario 3 are a combination of Scenarios 1 and 2.

Table 5 reveals job market impacts and income effects. Income gains, wage rises, and job creation are found in Cantabria, Asturias, La Rioja, Navarre, Aragon and the Balearic Islands, as the output gains achieved in these regions are sufficient to offset the structural changes in their economies caused via reallocation across sectors. Scenario 1 pushes up unemployment since overall output contracts. The policy implication is that any fiscal measure that reallocates production across sectors should cushion impacts of job and income losses caused by economic churning across and within regions. 
Table 5. Regional income and unemployment (\% variation with respect to the baseline scenario)

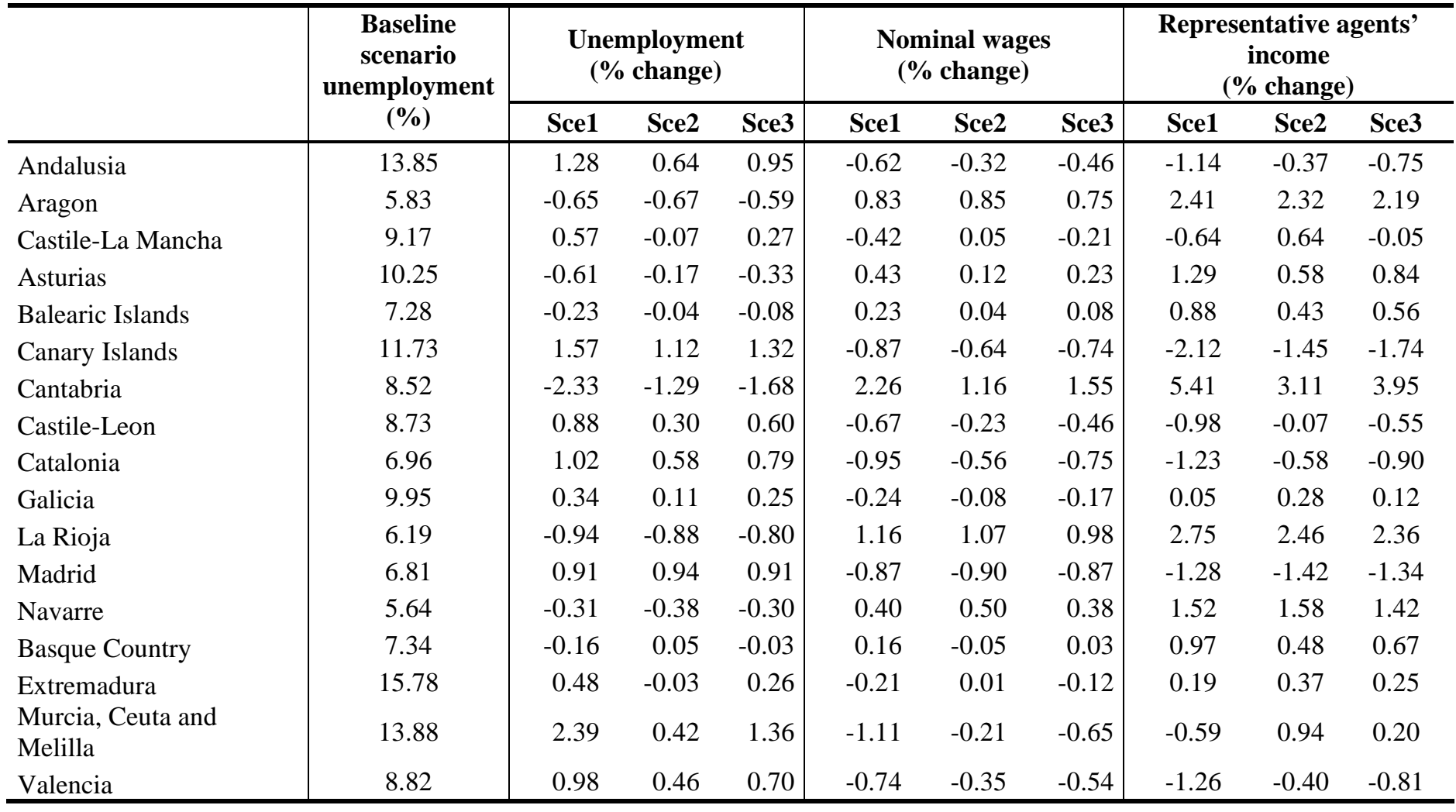

\section{Changes in water uses}

A key objective of this study is to examine the reduction of water use in regions suffering persistent acute water scarcity. Table SI8 of the SI show water impacts in agriculture and the agri-food industries. Change in the consumption of water is defined as the difference between the virtual water in the baseline scenario and the virtual water in each of the scenarios analysed (see subsection 3.3).

In Scenario 1, water used in farming (i.e. water embedded in agricultural output) declines in all regions - a 3.3\% reduction in Spain as a whole. Water consumption falls in the agrifood industries of all regions except Asturias. As a result, the policy upon which Scenario 1 is predicated produces $13.9 \%$ in water savings (embodied water) nationwide. Meanwhile, rising farm and agri-food prices in this scenario cause a drop in consumption and exports, which 
also reduces the value of water consumed beyond just those associated with declines in physical output.

Scenario 1 policies reduce water consumption most in Navarre, Aragon, Castile-La Mancha, Castile and Leon and Andalusia-indeed, by more than $13.7 \%$ in each. Water consumption also declines in the regions affected by severe water scarcity -Valencia $(11.8 \%)$, Madrid (11.4\%), Murcia (10.4\%) and the Canary Islands (3.6\%), even if just more scarce than the national average.

Scenario 2 policies reduce water consumption in the regions with low water availability, despite large increases in output shown in Table 3, mainly because of the previous declines in consumption shown in Table SI6. Overall, water savings are smaller by both sector and region when compared to findings for Scenario 1. The largest reductions are observed in regions in which water is most scarce (16.3\% in Murcia and $4.8 \%$ in Valencia) because the consumption tax approach drives sharp drops in regional consumption. Meanwhile, Spain's farmers and agri-food entrepreneurs reduce their total water consumption by $6.0 \%$, mainly because of falling consumption driven by the altered tax structure (see Table SI6), which shifts the onus onto the consumer. As expected, a mixed combination of results is observed in Scenario 3, in which reductions in water consumption are achieved across all of Spain's regions and in all of its sectors. The overall water saving for the country as a whole is $9.2 \%$.

To sum up, an environmental policy based on taxation of water scarcity and subsidies for water productivity could improve water efficiency and, thereby, create water savings in agrifood activities. This would help alleviate environmental pressures, especially if taxes are applied to production. This claim is confirmed by Table 6, which presents the scarcity levels for the Spanish regions in our scenarios and the percentage change compared to Table 1, which describes the baseline scenario. As may be observed, in Scenario 1 the water situation improves for all regions endowed with high levels of water scarcity. But the pressure 
increases on the water resources of regions with low water scarcity levels through rises in water-intensive production that are driven by the underlying policy. Similar findings are obtained when we use alternative water scarcity indexes (see Table SI11).

When taxes are applied on the consumption of goods with water content rather than on the production of goods with water content, water savings are still obtained in agriculture and agri-food industries (see Table SI8 of the SI), but they are insufficient to enable alter waterscarcity levels much in most regions. In fact, the Spanish economy increases overall water scarcity by $0.37 \%$ due to the increases in output generated in all regions, as shown in Table 3 . Still, very clear positive impacts are enabled and precisely in those regions suffering from severe water shortages, like the Canary Islands and Madrid, which appear to get slight improvements in water availability. 
Table 6. Level of blue water scarcity in Spanish regions

\begin{tabular}{lrrrrrr}
\hline \multirow{2}{*}{ Region } & \multicolumn{2}{c}{ Scenario 1 } & \multicolumn{2}{c}{ Scenario 2 } & \multicolumn{2}{c}{ Scenario 3 } \\
& Level & \% change & Level & \% change & Level & \% change \\
\hline Andalusia & 47.48 & -1.11 & 48.14 & 0.27 & 47.81 & -0.43 \\
Aragon & 55.66 & 2.14 & 55.71 & 2.23 & 55.61 & 2.05 \\
Castile-La Mancha & 33.75 & -0.32 & 34.27 & 1.21 & 33.99 & 0.38 \\
Asturias & 2.68 & 3.48 & 2.65 & 2.38 & 2.66 & 2.71 \\
Balearic Islands & 44.47 & 1.38 & 44.24 & 0.87 & 44.31 & 1.02 \\
Canary Islands & 86.71 & -0.89 & 87.05 & -0.51 & 86.89 & -0.69 \\
Cantabria & 6.06 & 9.30 & 5.84 & 5.29 & 5.92 & 6.81 \\
Castile and Leon & 21.36 & -0.59 & 21.74 & 1.15 & 21.54 & 0.22 \\
Catalonia & 54.67 & -1.33 & 55.27 & -0.25 & 54.97 & -0.78 \\
Galicia & 1.26 & 0.68 & 1.26 & 1.25 & 1.26 & 0.88 \\
La Rioja & 22.63 & 3.68 & 22.57 & 3.39 & 22.54 & 3.25 \\
Madrid & 156.67 & -1.00 & 156.68 & -1.00 & 156.69 & -0.99 \\
Navarre & 22.95 & 2.80 & 22.92 & 2.66 & 22.90 & 2.55 \\
Basque Country & 10.55 & 0.81 & 10.51 & 0.45 & 10.53 & 0.58 \\
Extremadura & 35.55 & 0.96 & 35.89 & 1.95 & 35.68 & 1.35 \\
Murcia & 276.83 & -1.66 & 284.04 & 0.90 & 280.44 & -0.38 \\
Valencia & 101.44 & -0.87 & 102.54 & 0.20 & 101.99 & -0.33 \\
Total & $\mathbf{2 7 . 8 6}$ & $-\mathbf{0 . 2 5}$ & $\mathbf{2 8 . 0 4}$ & $\mathbf{0 . 3 7}$ & $\mathbf{2 7 . 9 4}$ & $\mathbf{0 . 0 2}$ \\
\hline & & & & & &
\end{tabular}

\section{Changes in the external dependence of the food supply chain}

Another of study objectives is to analyse the external dependence of agri-food supply chains. As mentioned in our discussion of the research approach, we use ratios between an industry's total direct purchases and total direct purchases in the region itself (see Subsection 3.4). Table 7 presents the values of these ratios for the three scenarios simulated as a percentage difference from the baseline scenario shown in Table 2. 
Table 7. \% change in the external dependence of agri-food supply chains, compared to Table 2

\begin{tabular}{|c|c|c|c|c|c|c|c|c|c|c|c|c|}
\hline & \multicolumn{4}{|c|}{ Scenario1 } & \multicolumn{4}{|c|}{ Scenario 2} & \multicolumn{4}{|c|}{ Scenario 3} \\
\hline & 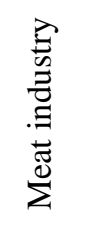 & 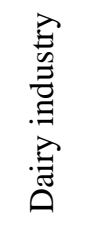 & 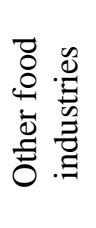 & 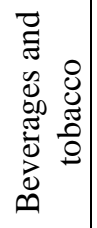 & 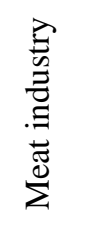 & 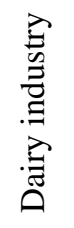 & 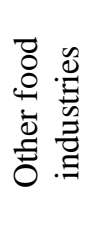 & 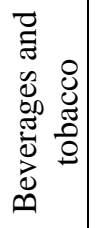 & 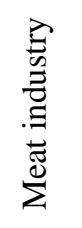 & 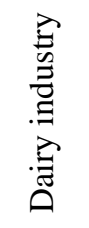 & 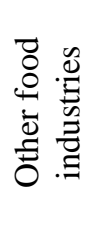 & 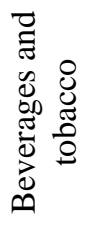 \\
\hline Andalusia & 1.5 & 1.4 & 0.9 & 2.6 & 1.1 & 1.3 & 0.8 & 1.5 & 1.2 & 1.3 & 0.8 & 1.9 \\
\hline Aragon & 4.1 & 2.3 & -0.6 & -3.8 & 3.3 & 1.7 & 0.7 & -0.7 & 3.6 & 1.9 & 0.0 & -2.5 \\
\hline Castile-La Mancha & 1.8 & 5.3 & 0.4 & 2.3 & 1.4 & 3.5 & 0.8 & 1.6 & 1.5 & 4.1 & 0.5 & 1.8 \\
\hline Asturias & -4.2 & 5.2 & -1.9 & 3.0 & -1.3 & 3.7 & 0.1 & 1.9 & -2.7 & 4.2 & -0.9 & 2.3 \\
\hline Balearic Islands & -2.5 & 0.4 & 1.0 & -1.2 & -0.4 & 1.1 & 2.1 & 2.1 & -1.3 & 0.8 & 1.4 & 0.6 \\
\hline Canary Islands & 1.6 & 2.7 & 0.8 & 0.8 & 2.2 & 2.0 & 1.0 & 0.6 & 2.0 & 2.2 & 0.8 & 0.7 \\
\hline Cantabria & -1.4 & -4.2 & -1.8 & -3.8 & 1.2 & 2.0 & 0.1 & 0.3 & -0.2 & -1.3 & -0.9 & -1.8 \\
\hline Castile and Leon & 6.2 & 7.7 & 2.0 & 2.6 & 3.7 & 5.1 & 1.7 & 2.0 & 4.6 & 6.0 & 1.7 & 2.2 \\
\hline Catalonia & 10.1 & 2.8 & 2.9 & 4.5 & 5.7 & 2.1 & 2.4 & 2.6 & 7.3 & 2.3 & 2.5 & 3.3 \\
\hline Galicia & 1.1 & 1.8 & 2.7 & 1.5 & 1.1 & 1.8 & 2.3 & 1.8 & 1.1 & 1.8 & 2.3 & 1.6 \\
\hline La Rioja & 1.9 & 4.9 & 2.0 & 3.0 & 2.6 & 5.8 & 1.9 & 2.3 & 2.3 & 5.4 & 1.8 & 2.5 \\
\hline Madrid & 13.3 & 15.2 & 7.6 & 2.4 & 7.4 & 8.3 & 4.9 & 2.2 & 9.5 & 10.7 & 5.8 & 2.2 \\
\hline Navarre & 0.2 & 3.5 & 3.2 & 3.0 & 1.5 & 9.9 & 2.9 & 3.6 & 0.9 & 6.8 & 2.9 & 3.3 \\
\hline Basque Country & 2.7 & 2.2 & 2.3 & 5.3 & 2.8 & 2.8 & 2.1 & 3.7 & 2.7 & 2.5 & 2.1 & 4.2 \\
\hline Extremadura & -0.3 & 1.1 & 2.1 & 2.1 & 1.1 & 3.8 & 2.3 & 1.8 & 0.5 & 2.7 & 2.0 & 1.9 \\
\hline Murcia & 5.6 & 11.8 & 4.3 & 6.3 & 4.8 & 8.6 & 3.9 & 4.2 & 5.1 & 9.8 & 3.8 & 4.9 \\
\hline Valencia & 1.9 & 6.1 & 3.8 & 5.3 & 2.2 & 4.1 & 2.8 & 3.8 & 2.0 & 4.8 & 3.1 & 4.3 \\
\hline Total regions & 0.8 & 0.9 & 0.6 & 0.9 & 0.0 & 0.0 & 0.1 & 0.0 & 0.7 & 1.0 & 0.6 & 0.8 \\
\hline
\end{tabular}

To begin, we observe that four of the regions with severe water scarcity (Madrid, the Canary Islands, Murcia and Valencia) display greater external dependence through a shift in production to less water-intensive crops and products. Meanwhile, the development of local agriculture and agri-food industries in the regions of northern Spain (e.g. Asturias, Cantabria and Aragon), in which more abundant water resources are enjoyed, results in less external 
dependence in some food supply chains. Furthermore, the scenarios also reduce external dependence in some food supply chains in the Balearic Islands.

\section{CONCLUSIONS AND FINAL REMARKS}

Imbalances between natural water availability and water demand across regions cause major economic and environmental asymmetries in Spain and other nations around the world. So altering food supply chains by imposing responsibility of the externalities associated with water use on producers and consumers is relevant economic policy. Such Pigouvian taxes have the potential to help Spanish society progress towards sustainable agriculture and agrifood industries. Strategies combining both of these goals are analysed in this paper. We address these issues using a multi-regional CGE model of Spain that enables an examination of resource imbalances across regions via alternative scenarios. Three scenarios use a set of economic and environmental indicators for water scarcity, farm productivity and interregional interdependence of the regional agri-food industries. In all scenarios, aggregate subsidies to the agri-food industries are set to the total net new Pigouvian tax revenues generated. In the first scenario, taxes are only paid by producers; in the second only by consumers; and the third is a 50:50 blend of a producer- and consumer-paid tax. Except in the regions suffering from severe water scarcity, regional agriculture receives more subsidies via a premium that is aligned with the productivity of water usage. Agri-food industries, however, are subsidized by region and industry according to the shares of intermediate inputs that are purchased locally.

Our results show that reduced water usage in agri-food industries is partially achieved under all three policies examined (producer pays, consumer pays and mixed payment). More interestingly our findings also suggest that governments should be able to stimulate production of water-intensive crops in regions that have greater water availability. But outcomes do differ depending on who pays. When taxes are paid by producers (Scenario 1), 
they mainly pass on the tax burden through retail prices for food products. The tax thus lowers demand for water-intensive goods and, also, specifically output of all goods that embody water in regions with severe water scarcity. Water consumption is thereby reduced considerably, driven by the emergence of more sustainable production and consumption patterns. This, in turn, alleviates water scarcity. This scenario also shortens food-supply chains and precipitates enhancements in the shares of locally sourced regional inputs.

Changes in food prices decline when the tax burden is borne by end-consumers (Scenario 2). In fact, consumption falls most steeply in the regions that suffer severe water scarcity; so they shoulder the lion's share of the new tax burden. On the other hand, this policy substantially stimulates production in agri-food industries since producers are freed from taxation and also receive subsidies. So in this case as well, agri-food industry water savings are focused in regions with in which water is acutely scarce. Unfortunately, the effect is not sufficiently strong to alleviate the pressure of water demand on other regions. Based on these insights, a blended Pigouvian tax regime could merge both objectives and yet ensure that producers and consumers share the tax burden.

Scenario 3 suggests steps in that direction. It encourages water saving and improves the agri-food industries' supply chains. It yields both a small gain in the total output of the economy as well as some overall water savings.

For Spain, a regional approach suggests improvements in farm output in regions with low levels of water scarcity, i.e., Cantabria, Asturias, La Rioja, Navarre, Aragon, the Basque Country (basically northern Spain) and the Balearic Islands (see Scenarios 1 and 3). In these scenarios, water-intensive production in regions with low water availability, i.e., Murcia, Valencia, Catalonia and Andalusia, is reigned in and interregionally reallocated to enable a more sustainable path for the nation's agri-food production. 
To conclude, this study reveals the potential of fiscal instruments to develop a more sustainable agri-food supply chain for Spain. They achieve water savings from both an environmental and economic perspective. Furthermore, taxes applied to both production and consumption, accompanied by subsidies to most-efficient producers suggest that responsibility for the cost of measures could be shared between consumers and producers. Such a policy appears likely enable growth while nudging production of water-intensive crops to regions with more abundant water resources while also saving water most in regions in which resources are presently most stretched. Therefore, regions with more water resources and higher productivity in agriculture would receive less regulatory attention. But income and job losses would be affected in regions with low water availability. This means these regions would need some sort of compensation to help restructure their economies, albeit with a focus on most-effective sustainable alternatives. In this regard, holistic policies should supplement these environmental pressures with social ones, something we did not examine. Meanwhile, other impacts such as the use of other resources, land degradation and greenhouse gas emissions also undoubtedly vary across regions, and the potential trade-offs and challenges arising in this respect should also be accounted. Thus, these policies and other taxes that combine to enable possible win-win situations across an array of important issues should be proposed and investigated simultaneously.

In this vein, our research is, then, a first, tentative step in the study of water consumption and policies that stimulate the reallocation of production across regions of a nation. Further work is needed to extend our research. In addition to the broader social implications alluded to above, it could consider other important issues such as water seasonality, long-term trends in water availability, and alternative measures under different technological and income assumptions across regions. Finally, the links between these approaches could open the door 
to similar analyses in other countries and regions beset by similar water challenges to those facing Spain.

\section{References}

Alcamo, J., T. Henrich and T. Rosch (2000) World Water in 2025 - Global modelling and scenario analysis for the World Commission on Water for the 21st Century. Report A0002, Centre for Environmental System Research, University of Kassel, Germany.

Armington, P. (1969) A theory of demand for products distinguished by place of production. International Monetary Fund Staff Papers, 19, 159-178.

Bergman, L. (2005) CGE modeling of environmental policy and resource management. In: K.G. Mäler and J. Vincent (eds.) Handbook of Environmental Economics: Economy Wide and International Environmental Issues. Elsevier, North Holland, 1273-1306.

Blanchflower, D.G. and A.J. Oswald (1990) The Wage Curve. Scandinavian Journal of Economics, 92, 215-235.

Boeters, S. and L. Savard (2012) The Labour Market in CGE Models Handbook of CGE Modeling (eds. P. Dixon and D. Jorgenson), North Holland.

Calzadilla, A., K. Rehdanz, R. Roson, M. Sartori and R.S.J. Tol (2017) Review of CGE models of water issues. In: Bryant, T. (ed.) Computable general equilibrium models. The WSPC reference on natural resources and environmental policy in the era of global change, 3. World Scientific, Singapore, 101-124. ISBN 9789814713740

Cazcarro, I., R. Duarte and J. Sanchez Choliz (2013) Multiregional input-output model for the evaluation of Spanish water flow. Environmental Science \& Technology, 47, 12275-12283.

Dietzenbacher, E. and E. Velazquez (2007) Analysing Andalusian virtual water trade in an input output framework. Regional Studies, 41, 185-196.

Duarte, R., K. Feng, H. Hubacek, J. Sánchez-Chóliz, C. Sarasa and L. Sun (2016) Modeling carbon consequences of pro-environmental behaviors of consumers in Spain. Applied Energy, 184, 1207-1216.

Estrela, T., M.A. Pérez-Martin, and E. Vargas (2012) Impacts of climate change on water resources in Spain. Hydrological Sciences Journal, 57, 1154-1167.

EU (2013) Short Food Supply Chains and Local Food Systems in the EU. A State of Play of their SocioEconomic Characteristics. Joint Research Centre, Report EUR 25911.

FAO (2019) Water Resources. Aquastat-Water; Food and Agriculture Organization: Rome, Italy 
García-Mainar, I. and V.M. Montuenga-Gómez (2012) Wage dynamics in Spain: evidence from individual data (1994-2001). Investigaciones Regionales, 24, 41-58.

Hoekstra, A.Y., A.K. Chapagain, M.M. Aldaya, and M.M. Mekonnen (2011) The water footprint assessment manual: Setting the global standard. Earthscan, London, UK, ISBN: 978-1-84971-279- 8

IGME (2015) Statistical data. Geological and mining institute of Spain (IGME in Spanish). Ministry of economy and competitiveness, Madrid.

ISO_14046 (2014) Waterfootprint_principles, requirements and guidelines.

Lenzen, M., D. Moran, A. Bhaduri, K. Kanemoto, M. Bekchanov, A. Geschke and B. Foran (2013) International trade of scarce water. Ecological Economics, 94, 78-85.

Llop, M. and X. Ponce-Alifonso (2016) Water and Agriculture in a Mediterranean Region: The Search of a Sustainable Water Policy Strategy. Water, 8, 66-80.

MAPAMA (2005a) Costs and prices of water- Ministry of Agricululture, Food and Environment, Madrid, Spain.

MAPAMA (2005b) Yearbook of Agricultural Statistics. Ministry of Agricululture, Food and Environment, Madrid, Spain.

MAPAMA (2015a) Monitoring and Control Network of the Chemical State / Surface waters / Quantitative Status Monitoring Network. Ministry of agriculture, fisheries, food and environment (MAPAMA in Spanish).

MAPAMA (2015b) Simulación precipitación-aportación (simpa). Ministerio de Agricultura, limentación y Medio Ambiente. Available online: http://hispagua.cedex.es/datos/climatologia (accessed on 22 April 2015).

MAPAMA (2015c) Sistema integrado de información del agua (sia). Ministerio de Agricultura, Alimentación y Medio Ambiente. Available online: http://servicios2.marm.es/sia/visualizacion/ descargas/capas.jsp (accessed on 22 April 2015). (In Spanish)

Mekonnen, M. and A.Y. Hoekstra (2011) The green, blue and grey water footprint of crops and derived crop products. Hydrology and Earth System Sciences, 15, 1577-1600.

MSSI (2015) Quality of drinking water. Ministry of Health, Social Services and Equality (MSSI in Spanish).

NSI (2016) Survey of water usage in the agricultural sector. 2000-2015 series. National Statistics Institute, Madrid, Spain.

NSI (2014) Survey on water supply and sewerage. 2000-2014 Series. National Statistics Institute, Madrid, Spain. 
NSI (2010) Satellite water accounts in Spain. 1997-2001 series (regional and basin detail). 2000-2006 series. 2007-2010 series. National Statistics Institute, Madrid, Spain.

Pfister, S., A., Koehler and S. Hellweg (2009) Assessing the environmental impacts of freshwater consumption in LCA. Environment Science \& Technology, 43, 4098-4104.

Philip, J.M., J. Sánchez-Chóliz and C. Sarasa (2014) Technological change in irrigated agriculture in a semi-arid region of Spain. Water Resources Research, 50, 9221-9235.

Quinteiro, P., S. Rafael, P. Villanueva-Rey, B. Ridoutt, M. Lopes, L. Arroja and A.C. Dias (2018). A characterisation model to address the environmental impact of green water flows for water scarcity footprints. Science of the Total Environment, 626, 1210-1218.

SIMPA (2010) Simulación precipitación-aportación (simpa). Libro digital del agua (marm) 941-2009; Centro de Estudios y Experimentación de Obras Públicas (CEDEX): Madrid, Spain, 2010. (In Spanish).

Wiedmann, T. (2009) A review of recent multi-region input-output models used for consumption based emission and resource accounting. Ecological Economics, 69, 211-222. 


\section{Supplementary Information}

Table SI1. Elasticity parameters and water prices

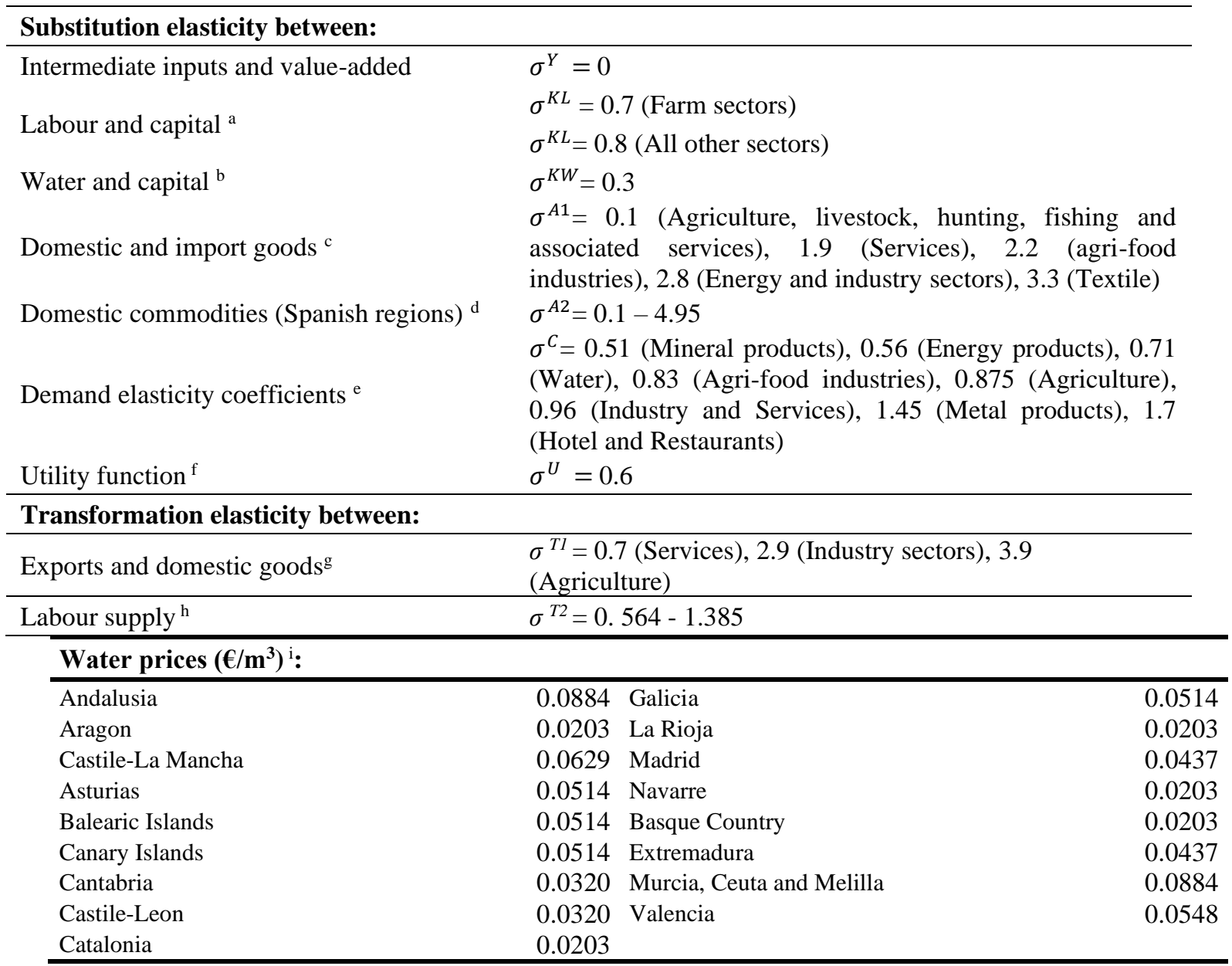

Note: ranges are for the commodities.

a The value of the elasticity between labour and capital is obtained from the work of Seung et al., (1998) for the economy of California, given the similarity of climate and land conditions. Additionally, the substitution between labour and capital is lower in the farm sectors because the aggregate of capital and water is very significant in these sectors, in line with the work of Jomini et al., (1991) for the global economy.

b The elasticity substitution between capital and water is obtained from the work of Gómez et al. (2004) for the Balearic Islands, where they assume different values depending on the crop. Olives and vineyards use 0.1 , fruit and vegetables use 0.2, and industrial crops use 0.3. We use 0.3 as a median value for all crops in Spain.

c Armington elasticities are differenced by sector and obtained from Hertel (1997) for the global economy as a medium value.

${ }^{\mathrm{d}}$ Large values are assumed for the substitution between domestic commodities in the Spanish regions following the recommendations made in Tsigas (1997). In particular, these elasticities increase the Armington values per region by one and a half times. However, as our simulations include agriculture, a sector that is not easily reallocated, we include a lower value of elasticity at 0.1 . Also, the elasticity values of regions located in the Spanish archipelagos (Balearics and Canaries) are not increased with respect to the elasticities between domestic and imported goods.

${ }^{\mathrm{e}}$ All sector demand elasticity coefficients are taken from Mainar (2010) for the Spanish economy.

${ }^{\mathrm{f}}$ This value is obtained from the work of De Schoutheete (2012) for the Spanish economy.

g CET elasticities are differenced by sector and obtained from De Melo and Tarr (1992) for the US economy, the usual benchmark in the literature.

${ }^{\text {h }}$ Own work based on Spanish regional data from NSI (2005). See information by region in Table 5.

I MAPAMA (2005). 
Table SI2. Water use, water availability $\left(\mathrm{km}^{3}\right)$ and water scarcity in the Spanish regions

\begin{tabular}{|c|c|c|c|c|c|c|c|c|c|c|c|}
\hline Region & $\begin{array}{c}\text { Blue water } \\
\text { use }\end{array}$ & $\begin{array}{c}\text { Green water } \\
\text { use }\end{array}$ & $\begin{array}{c}\text { Water } \\
\text { availability } \\
\text { (Run-off) }\end{array}$ & $\begin{array}{c}\text { Blue } \\
\text { Water } \\
\text { scarcity }\end{array}$ & $\begin{array}{l}\text { Blue \& } \\
\text { green } \\
\text { Water } \\
\text { scarcity }\end{array}$ & Region & $\begin{array}{c}\text { Blue water } \\
\text { use }\end{array}$ & $\begin{array}{c}\text { Green water } \\
\text { use }\end{array}$ & $\begin{array}{c}\text { Water } \\
\text { availability } \\
\text { (Run-off) }\end{array}$ & $\begin{array}{c}\text { Bue } \\
\text { Water } \\
\text { scarcity }\end{array}$ & $\begin{array}{c}\text { Blue \& } \\
\text { green } \\
\text { Water } \\
\text { scarcity }\end{array}$ \\
\hline Andalusia & 3,352 & 12,339 & 13,850 & $\mathrm{M}$ & $\mathrm{Se}$ & Galicia & 217 & 2,195 & 25,809 & $\mathrm{~L}$ & $\mathrm{~L}$ \\
\hline Aragon & 2,445 & 3,514 & 6,169 & $\mathrm{Si}$ & $\mathrm{Se}$ & La Rioja & 126 & 587 & 1,212 & $\mathrm{~L}$ & $\mathrm{Se}$ \\
\hline $\begin{array}{l}\text { Castile-La } \\
\text { Mancha }\end{array}$ & 1,304 & 7,518 & 6,571 & $\mathrm{~L}$ & $\mathrm{Se}$ & Madrid & 718 & 337 & 1,455 & $\mathrm{Se}$ & $\mathrm{Se}$ \\
\hline Asturias & 164 & 362 & 7,450 & $\mathrm{~L}$ & $\mathrm{~L}$ & Navarre & 532 & 868 & 4,152 & $\mathrm{~L}$ & $\mathrm{Si}$ \\
\hline Balearic Islands & 220 & 530 & 652 & $\mathrm{Si}$ & $\mathrm{Se}$ & $\begin{array}{l}\text { Basque } \\
\text { Country }\end{array}$ & 346 & 335 & 4,607 & $\mathrm{~L}$ & $\mathrm{~L}$ \\
\hline Canary Islands & 312 & 405 & 778 & $\mathrm{Se}$ & $\mathrm{Se}$ & $\begin{array}{l}\text { Extremadura } \\
\text { Murcia, }\end{array}$ & 1,192 & 2,525 & 6,293 & $\mathrm{~L}$ & $\mathrm{Se}$ \\
\hline Cantabria & 188 & 180 & 3,869 & $\mathrm{~L}$ & $\mathrm{~L}$ & $\begin{array}{l}\text { Ceuta \& } \\
\text { Melilla }\end{array}$ & 859 & 516 & 444 & $\mathrm{Se}$ & $\mathrm{Se}$ \\
\hline Castile \& Leon & 1,877 & 7,626 & 18,638 & $\mathrm{~L}$ & $\mathrm{Se}$ & Valencia & 1,910 & 924 & 2,642 & $\mathrm{Se}$ & $\mathrm{Se}$ \\
\hline Catalonia & 2,004 & 2,730 & 4,042 & $\mathrm{Se}$ & $\mathrm{Se}$ & Total & 17,767 & 43,492 & 108,631 & $\mathrm{~L}$ & $\mathrm{Se}$ \\
\hline
\end{tabular}

Note: Se: Severe, Si: Significant; M: Moderate; L: Low. 
Table SI3. \% Application of subsidies and tax rates

\begin{tabular}{lcccccc}
\hline & \multicolumn{5}{c}{ Subsidies } & \\
\cline { 2 - 5 } Region & Agriculture & $\begin{array}{r}\text { Meat } \\
\text { industry }\end{array}$ & $\begin{array}{r}\text { Dairy } \\
\text { industry }\end{array}$ & $\begin{array}{r}\text { Other food } \\
\text { industries }\end{array}$ & $\begin{array}{r}\text { Beverages } \\
\text { and } \\
\text { tobacco }\end{array}$ & $\begin{array}{r}\text { Tax rates in agricultural } \\
\text { and agri-food sectors. }\end{array}$ \\
\hline Andalusia & 5.01 & 8.58 & 9.32 & 21.20 & 6.52 & 4.86 \\
Aragon & 3.74 & 7.40 & 7.63 & 7.82 & 17.99 & 5.59 \\
Castile-La Mancha & 2.90 & 6.51 & 6.12 & 8.78 & 7.02 & 3.47 \\
Asturias & 10.62 & 9.86 & 6.96 & 4.00 & 0.41 & 0.26 \\
Balearic Islands & 5.17 & 3.82 & 2.28 & 1.33 & 4.62 & 4.18 \\
Canary Islands & 0.00 & 0.97 & 0.91 & 1.99 & 2.80 & 8.10 \\
Cantabria & 19.40 & 6.10 & 5.73 & 4.74 & 4.80 & 0.56 \\
Castile-Leon & 3.68 & 8.96 & 12.03 & 11.15 & 6.47 & 2.18 \\
Catalonia & 7.36 & 6.96 & 8.39 & 4.74 & 4.22 & 5.54 \\
Galicia & 11.49 & 10.71 & 13.99 & 7.20 & 6.59 & 0.12 \\
La Rioja & 6.38 & 1.59 & 2.43 & 1.78 & 6.59 & 2.22 \\
Madrid & 0.00 & 1.07 & 1.15 & 0.87 & 7.66 & 15.34 \\
Navarre & 5.52 & 7.54 & 3.31 & 5.00 & 7.75 & 2.31 \\
Basque Country & 12.44 & 5.32 & 11.04 & 3.92 & 5.08 & 1.09 \\
Extremadura & 6.29 & 4.56 & 3.77 & 8.04 & 3.11 & 3.71 \\
Murcia, Ceuta and Melilla & 0.00 & 1.84 & 1.18 & 4.06 & 1.54 & 29.87 \\
Valencia & 0.00 & 8.23 & 3.75 & 3.35 & 6.81 & 10.61 \\
\hline TOTAL & 100.00 & 100.00 & 100.00 & 100.00 & 100.00 & 100.00 \\
\hline & & & & & & \\
\hline
\end{tabular}

Source: Own work. Note: The tax rate is the same in each sector and scenario, but the taxes applied to production (Scenario 1) and consumption (Scenario 2) differ because of the level of taxation needed to achieve the $€ 10$ billion take required to support subsidies. 
Table SI4. Impacts on output volumes (\% change with respect to the baseline scenario)

\begin{tabular}{|c|c|c|c|c|c|c|c|c|c|c|c|c|c|c|c|}
\hline & \multicolumn{5}{|c|}{ Scenario 1} & \multicolumn{5}{|c|}{ Scenario 2} & \multicolumn{5}{|c|}{ Scenario 3} \\
\hline & 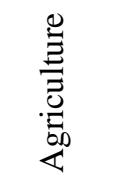 & 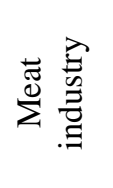 & 吢芯 & 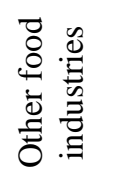 & 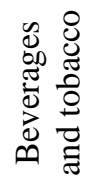 & 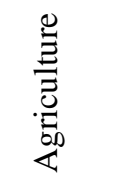 & 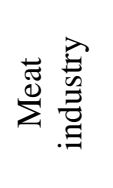 & 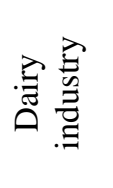 & 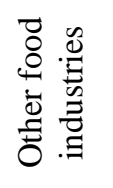 & 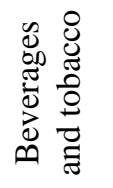 & $\frac{\stackrel{0}{\Xi}}{\frac{.}{0}}$ & 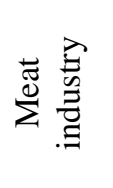 & 忌宫 & 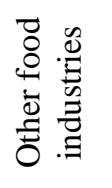 & $\begin{array}{l}0 \\
0 \\
0 \\
0 \\
0 \\
\tilde{0} \\
0 \\
0 \\
0 \\
0 \\
0 \\
0\end{array}$ \\
\hline Andalusia & -9.49 & -14.77 & 14.78 & -12.22 & -15.59 & 7.82 & 12.80 & 26.51 & 14.40 & 5.05 & -0.96 & -2.16 & 18.37 & 0.45 & -5.71 \\
\hline Aragon & -9.31 & -3.59 & 9.76 & 10.52 & 340.02 & 9.65 & 21.72 & 22.34 & 31.08 & 238.52 & -0.12 & 7.50 & 14.07 & 19.72 & 275.95 \\
\hline Castile-La Mancha & -6.47 & -11.00 & -2.57 & 8.84 & -7.20 & 8.79 & 13.19 & 13.81 & 26.09 & 8.80 & 0.99 & 0.02 & 4.40 & 16.56 & 0.17 \\
\hline Asturias & 135.99 & 123.09 & 3.39 & 25.51 & -3.72 & 74.28 & 108.25 & 14.45 & 34.98 & 8.16 & 98.57 & 110.43 & 7.63 & 29.07 & 1.70 \\
\hline Balearic Islands & 66.15 & 43.36 & 70.75 & -0.88 & 62.44 & 44.75 & 52.95 & 55.60 & 19.98 & 52.92 & 52.15 & 45.17 & 57.80 & 8.77 & 54.09 \\
\hline Canary Islands & -16.31 & 28.91 & -9.65 & -2.77 & -4.29 & 6.23 & 44.08 & 11.40 & 20.36 & 13.34 & -5.18 & 33.60 & -0.25 & 7.83 & 3.44 \\
\hline Cantabria & 257.07 & 86.02 & 242.72 & 28.83 & 126.14 & 134.75 & 77.65 & 152.86 & 37.28 & 86.07 & 184.79 & 77.36 & 183.01 & 31.87 & 99.78 \\
\hline Castile-Leon & -5.41 & -17.34 & 14.26 & -4.12 & 10.65 & 8.68 & 8.74 & 23.73 & 16.61 & 18.63 & 1.51 & -5.08 & 16.93 & 5.65 & 13.26 \\
\hline Catalonia & -1.21 & -26.99 & 2.22 & -19.95 & -16.04 & 13.09 & 4.34 & 17.84 & 6.19 & 4.66 & 5.36 & -12.11 & 8.40 & -7.33 & -6.11 \\
\hline Galicia & 15.36 & 23.72 & 30.51 & -8.20 & 33.39 & 17.23 & 36.19 & 31.57 & 11.54 & 30.17 & 15.34 & 27.88 & 28.22 & 1.34 & 29.46 \\
\hline La Rioja & 66.38 & 25.85 & 55.54 & -4.82 & 6.99 & 41.86 & 35.48 & 44.49 & 13.37 & 15.97 & 50.68 & 28.29 & 45.52 & 3.82 & 10.29 \\
\hline Madrid & -23.93 & -35.67 & -27.46 & -31.07 & -7.19 & 6.63 & 3.70 & 6.73 & 5.70 & 20.58 & -9.12 & -17.42 & -11.50 & -13.73 & 5.11 \\
\hline Navarre & 35.21 & 38.85 & 137.07 & -5.42 & 61.95 & 28.32 & 47.82 & 93.42 & 15.16 & 49.28 & 29.77 & 40.51 & 106.09 & 4.33 & 51.93 \\
\hline Basque Country & 133.09 & 70.19 & 103.89 & -5.37 & 3.07 & 72.61 & 66.37 & 74.28 & 13.29 & 13.44 & 96.13 & 64.13 & 82.03 & 3.50 & 7.27 \\
\hline Extremadura & 1.18 & 22.39 & 46.90 & -5.12 & -5.95 & 12.96 & 41.01 & 47.34 & 19.67 & 11.03 & 6.49 & 29.13 & 43.14 & 6.40 & 1.66 \\
\hline Murcia & -48.23 & -42.80 & -36.19 & -44.28 & -44.50 & 8.72 & 26.39 & 25.26 & 20.10 & 12.19 & -21.53 & -13.01 & -9.39 & -15.57 & -18.98 \\
\hline Valencia & -18.57 & -5.41 & -10.07 & -22.37 & -7.28 & 6.12 & 25.45 & 14.05 & 8.40 & 14.86 & -6.45 & 8.00 & 0.55 & -7.78 & 2.56 \\
\hline
\end{tabular}

Note: This table shows impacts in output volumes, without including effects on production prices. 
Table SI5. Regional and sector production prices (\% change with respect to the baseline scenario)

\begin{tabular}{|c|c|c|c|c|c|c|c|c|c|c|c|c|c|c|c|}
\hline & \multicolumn{5}{|c|}{$\begin{array}{c}\text { Scenario } 1 \\
\text { (Taxes on production) }\end{array}$} & \multicolumn{5}{|c|}{$\begin{array}{c}\text { Scenario } 2 \\
\text { (Taxes on consumption) }\end{array}$} & \multicolumn{5}{|c|}{$\begin{array}{c}\text { Scenario } 3 \\
\text { (Taxes on production and consumption) }\end{array}$} \\
\hline & 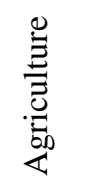 & 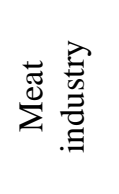 & 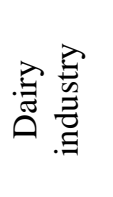 & 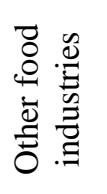 & 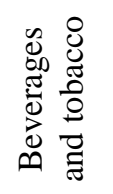 & 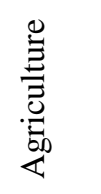 & 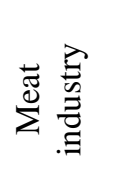 & :己 & 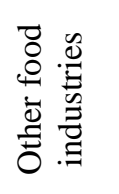 & 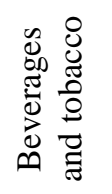 & 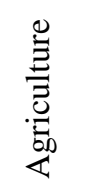 & 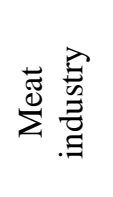 & 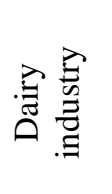 & 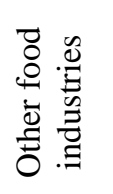 & 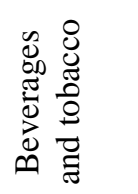 \\
\hline Andalusia & 6.05 & 11.46 & 10.71 & 12.73 & 7.23 & -0.67 & -0.71 & -0.78 & -0.53 & -0.94 & 2.52 & 4.85 & 4.43 & 5.46 & 2.96 \\
\hline Aragon & 12.46 & 15.13 & 11.48 & 14.22 & 16.46 & 0.18 & 0.57 & 0.50 & 0.81 & 1.32 & 5.72 & 7.07 & 5.45 & 6.89 & 8.12 \\
\hline Castile-La Mancha & 5.23 & 7.37 & 6.69 & 6.56 & 5.07 & -0.53 & -0.73 & -0.79 & -0.67 & -0.71 & 2.17 & 3.01 & 2.70 & 2.69 & 2.03 \\
\hline Asturias & 3.04 & 13.12 & 5.88 & 5.55 & 1.20 & 0.15 & 3.05 & 1.29 & 1.02 & -0.17 & 1.37 & 7.25 & 3.26 & 3.05 & 0.45 \\
\hline Balearic Islands & 6.69 & 10.49 & 6.47 & 8.54 & 8.74 & -0.28 & 0.25 & -0.17 & -0.32 & -0.06 & 2.94 & 4.83 & 2.93 & 3.80 & 3.99 \\
\hline Canary Islands & 10.32 & 10.03 & 8.71 & 9.63 & 9.31 & -0.77 & -1.08 & -1.44 & -1.19 & -1.14 & 4.46 & 4.21 & 3.42 & 3.97 & 3.85 \\
\hline Cantabria & 7.95 & 10.69 & 10.34 & 8.78 & 9.00 & 2.13 & 3.75 & 3.75 & 3.08 & 3.39 & 4.55 & 6.76 & 6.60 & 5.56 & 5.85 \\
\hline Castile-Leon & 3.86 & 7.74 & 7.09 & 6.70 & 4.09 & -0.51 & -0.57 & -0.63 & -0.48 & -0.51 & 1.52 & 3.18 & 2.87 & 2.84 & 1.69 \\
\hline Catalonia & 7.79 & 11.08 & 8.26 & 7.58 & 6.64 & -1.04 & -1.35 & -1.07 & -0.98 & -1.10 & 3.12 & 4.35 & 3.31 & 3.13 & 2.63 \\
\hline Galicia & 1.23 & 7.04 & 5.78 & 3.45 & 1.37 & -0.51 & 0.15 & -0.05 & -0.39 & -0.62 & 0.25 & 3.12 & 2.49 & 1.35 & 0.30 \\
\hline La Rioja & 3.23 & 5.08 & 5.08 & 3.72 & 4.36 & -0.03 & 0.58 & 0.58 & 0.23 & 0.05 & 1.47 & 2.67 & 2.67 & 1.86 & 2.08 \\
\hline Madrid & 21.36 & 24.80 & 24.36 & 23.31 & 26.66 & -1.14 & -1.26 & -1.22 & -1.23 & -1.01 & 8.99 & 10.28 & 10.15 & 9.73 & 11.22 \\
\hline Navarre & 4.94 & 9.51 & 6.58 & 7.56 & 5.58 & -0.14 & 0.93 & 0.27 & 0.43 & 0.24 & 2.22 & 4.78 & 3.20 & 3.69 & 2.74 \\
\hline Basque Country & 2.01 & 5.11 & 6.51 & 3.17 & 3.08 & -0.31 & 0.20 & 0.18 & -0.35 & -0.42 & 0.77 & 2.49 & 3.01 & 1.33 & 1.25 \\
\hline Extremadura & 5.94 & 13.44 & 12.93 & 12.72 & 7.59 & -0.64 & -0.31 & -0.46 & -0.42 & -0.83 & 2.47 & 6.00 & 5.60 & 5.63 & 3.20 \\
\hline Murcia & 78.32 & 80.46 & 72.13 & 77.91 & 69.67 & -3.03 & -7.14 & -7.30 & -5.16 & -5.40 & 26.22 & 25.34 & 22.93 & 25.64 & 23.13 \\
\hline Valencia & 13.38 & 20.35 & 14.59 & 14.46 & 15.49 & -0.66 & -0.94 & -1.42 & -1.30 & -1.23 & 5.87 & 8.63 & 6.00 & 6.03 & 6.50 \\
\hline
\end{tabular}

Source: Own work. 
Table SI6. Impacts on private consumption (\% change with respect to the baseline scenario)

\begin{tabular}{|c|c|c|c|c|c|c|c|c|c|c|c|c|c|c|c|}
\hline & \multicolumn{5}{|c|}{$\begin{array}{c}\text { Scenario } 1 \\
\text { (Taxes on production) }\end{array}$} & \multicolumn{5}{|c|}{$\begin{array}{c}\text { Scenario } 2 \\
\text { (Taxes on consumption) }\end{array}$} & \multicolumn{5}{|c|}{$\begin{array}{c}\text { Scenario } 3 \\
\text { (Taxes on production and consumption) }\end{array}$} \\
\hline & $\frac{\stackrel{0}{\Xi}}{\underbrace{0}_{0}}$ & 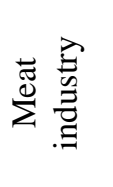 & 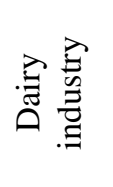 & 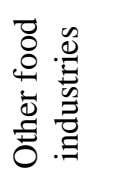 & 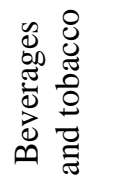 & 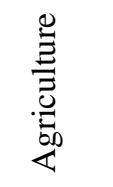 & 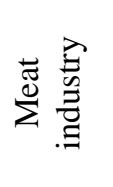 & 䔍泀 & 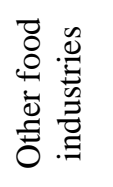 & 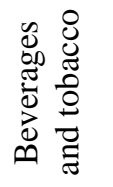 & $\frac{\stackrel{0}{\Xi}}{\frac{D}{\Xi}}$ & 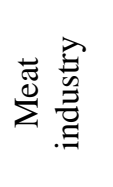 & 礻 & 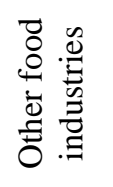 & 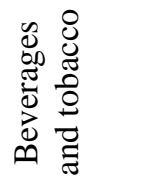 \\
\hline Andalusia & -1.07 & -2.11 & -0.14 & -1.66 & 0.40 & -1.29 & -1.24 & -0.58 & -1.68 & -0.86 & -1.01 & -1.55 & -0.21 & -1.44 & -0.13 \\
\hline Aragon & -4.22 & -4.10 & -2.65 & -6.44 & -8.61 & -3.23 & -2.82 & -2.48 & -4.68 & -6.46 & -3.39 & -3.18 & -2.27 & -5.08 & -7.06 \\
\hline Castile-La Mancha & -4.81 & -5.86 & -1.18 & -7.72 & -4.36 & -3.38 & -4.02 & -0.49 & -5.28 & -3.49 & -3.84 & -4.75 & -0.76 & -5.98 & -3.67 \\
\hline Asturias & -3.08 & -0.62 & -3.25 & -5.38 & 4.09 & -1.57 & 0.50 & -2.04 & -2.28 & 1.51 & -2.07 & -0.15 & -2.40 & -3.32 & 2.83 \\
\hline Balearic Islands & -2.56 & -2.27 & -3.26 & -3.35 & -0.22 & -1.53 & -0.56 & -2.49 & -2.00 & -0.88 & -1.83 & -1.33 & -2.63 & -2.37 & -0.40 \\
\hline Canary Islands & -2.14 & -4.87 & -0.16 & -2.86 & -2.40 & -1.68 & -2.65 & 0.06 & -1.81 & -2.39 & -1.77 & -3.57 & -0.05 & -2.17 & -2.20 \\
\hline Cantabria & -7.90 & -3.59 & N.A & -10.24 & N.A & -3.60 & -1.43 & N.A & -4.81 & N.A & -5.22 & -2.57 & N.A & -6.68 & N.A \\
\hline Castile-Leon & -5.03 & -4.98 & -3.63 & -6.03 & -4.51 & -2.61 & -2.37 & -1.96 & -3.24 & -2.88 & -3.52 & -3.48 & -2.48 & -4.21 & -3.33 \\
\hline Catalonia & -3.24 & -3.82 & -1.70 & -3.19 & -2.46 & -2.93 & -3.02 & -2.22 & -2.88 & -3.17 & -2.96 & -3.31 & -1.85 & -2.89 & -2.68 \\
\hline Galicia & -2.28 & -4.02 & -2.44 & -1.83 & -0.38 & -1.05 & -1.74 & -1.36 & -0.74 & -0.65 & -1.47 & -2.73 & -1.64 & -1.09 & -0.36 \\
\hline La Rioja & -4.98 & -8.36 & -6.77 & -3.50 & -5.13 & -2.46 & -4.22 & -4.04 & -1.20 & -2.79 & -3.39 & -5.84 & -4.84 & -2.17 & -3.58 \\
\hline Madrid & 1.04 & -0.23 & 1.87 & 1.19 & 1.36 & 0.67 & 0.25 & 0.60 & 1.15 & 0.15 & 0.99 & 0.16 & 1.35 & 1.28 & 0.94 \\
\hline Navarre & -6.32 & -8.11 & -5.90 & -5.76 & -6.30 & -3.86 & -5.12 & -4.18 & -3.26 & -4.76 & -4.76 & -6.28 & -4.63 & -4.20 & -5.14 \\
\hline Basque Country & -3.91 & -7.68 & -4.54 & -3.58 & -2.99 & -2.92 & -5.10 & -2.94 & -2.65 & -3.04 & -3.23 & -6.09 & -3.50 & -2.96 & -2.85 \\
\hline Extremadura & -2.90 & -4.94 & -2.80 & -3.10 & -1.15 & -2.20 & -2.88 & -2.09 & -2.25 & -1.69 & -2.25 & -3.60 & -2.07 & -2.37 & -1.17 \\
\hline Murcia & -2.51 & -4.47 & -1.78 & -2.26 & -2.15 & -16.88 & -16.75 & -15.22 & -16.84 & -17.52 & -8.20 & -9.08 & -7.06 & -8.05 & -8.34 \\
\hline Valencia & -2.82 & -5.95 & -0.96 & -2.13 & -3.10 & -3.14 & -4.70 & -2.30 & -2.72 & -3.51 & -2.83 & -5.03 & -1.50 & -2.32 & -3.14 \\
\hline Total consumption & -2.98 & -4.08 & -1.96 & -3.13 & -2.11 & -3.77 & -2.95 & -1.88 & -3.11 & -3.29 & -3.02 & -3.32 & -1.69 & -2.81 & -2.42 \\
\hline
\end{tabular}

Note: N.A means data is not available.

Source: Own work. 
Table SI7. Production in the calibration year. 2005

\begin{tabular}{|c|c|c|c|c|c|c|c|c|c|c|}
\hline & \multicolumn{2}{|c|}{ Agriculture } & \multicolumn{2}{|c|}{ Meat industry } & \multicolumn{2}{|c|}{ Dairy industry } & \multicolumn{2}{|c|}{ Other food industries } & \multicolumn{2}{|c|}{ Beverages and tobacco } \\
\hline & Billions & $\%$ & Billions & $\%$ & Billions & $\%$ & Billions & $\%$ & Billions & $\%$ \\
\hline Andalusia & 10.922 & 23.45 & 2.178 & 10.42 & 0.883 & 8.48 & 8.229 & 19.56 & 4.704 & 22.56 \\
\hline Aragon & 3.095 & 6.65 & 1.005 & 4.81 & 0.810 & 7.78 & 1.139 & 2.71 & 0.212 & 1.02 \\
\hline Castile-La Mancha & 3.801 & 8.16 & 1.605 & 7.67 & 1.221 & 11.72 & 1.671 & 3.97 & 2.535 & 12.16 \\
\hline Asturias & 0.563 & 1.21 & 0.262 & 1.25 & 1.098 & 10.55 & 0.510 & 1.21 & 0.148 & 0.71 \\
\hline Balearic Islands & 0.486 & 1.04 & 0.218 & 1.04 & 0.096 & 0.92 & 0.339 & 0.81 & 0.251 & 1.20 \\
\hline Canary Islands & 0.850 & 1.82 & 0.070 & 0.33 & 0.249 & 2.39 & 0.526 & 1.25 & 0.669 & 3.21 \\
\hline Cantabria & 0.529 & 1.14 & 0.221 & 1.06 & 0.081 & 0.78 & 0.524 & 1.25 & 0.149 & 0.71 \\
\hline Castile-Leon & 4.970 & 10.67 & 3.358 & 16.06 & 1.277 & 12.26 & 3.590 & 8.53 & 1.031 & 4.95 \\
\hline Catalonia & 4.151 & 8.91 & 7.204 & 34.45 & 1.267 & 12.16 & 8.497 & 20.20 & 3.538 & 16.97 \\
\hline Galicia & 3.752 & 8.06 & 0.897 & 4.29 & 1.061 & 10.19 & 3.696 & 8.79 & 0.643 & 3.09 \\
\hline La Rioja & 0.641 & 1.38 & 0.133 & 0.64 & 0.126 & 1.21 & 0.702 & 1.67 & 1.182 & 5.67 \\
\hline Madrid & 0.385 & 0.83 & 1.352 & 6.47 & 0.666 & 6.40 & 2.287 & 5.44 & 1.136 & 5.45 \\
\hline Navarre & 0.889 & 1.91 & 0.467 & 2.23 & 0.081 & 0.78 & 1.659 & 3.94 & 0.447 & 2.15 \\
\hline Basque Country & 0.683 & 1.47 & 0.243 & 1.16 & 0.344 & 3.30 & 1.654 & 3.93 & 1.128 & 5.41 \\
\hline Extremadura & 3.381 & 7.26 & 0.343 & 1.64 & 0.190 & 1.83 & 2.096 & 4.98 & 0.887 & 4.25 \\
\hline Murcia. Ceuta and Melilla & 4.068 & 8.74 & 0.323 & 1.55 & 0.184 & 1.77 & 1.561 & 3.71 & 0.731 & 3.50 \\
\hline Valencia & 3.404 & 7.31 & 1.033 & 4.94 & 0.781 & 7.50 & 3.386 & 8.05 & 1.458 & 6.99 \\
\hline Total & 46.567 & 100.00 & 20.913 & 100.00 & 10.416 & 100.00 & 42.067 & 100.00 & 20.848 & 100.00 \\
\hline
\end{tabular}

Source: Own work. 
Table SI8. Impacts on embodied water (\% change with respect to the baseline scenario)

\begin{tabular}{|c|c|c|c|c|c|c|c|c|c|c|c|c|c|c|c|c|c|c|}
\hline & \multicolumn{6}{|c|}{$\begin{array}{c}\text { Scenario 1 } \\
\text { (Taxes on production) }\end{array}$} & \multicolumn{6}{|c|}{$\begin{array}{c}\text { Scenario } 2 \\
\text { (Taxes on consumption) }\end{array}$} & \multicolumn{6}{|c|}{$\begin{array}{c}\text { Scenario } 3 \\
\text { (Taxes on production and consumption) }\end{array}$} \\
\hline & 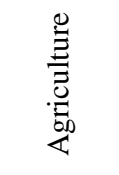 & 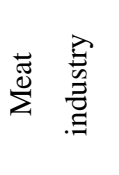 & 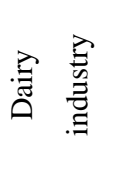 & 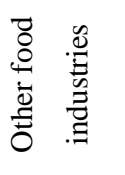 & 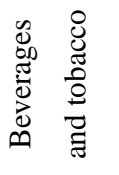 & 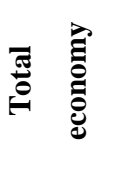 & 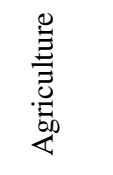 & 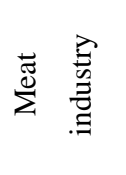 & 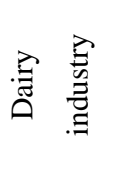 & 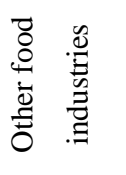 & 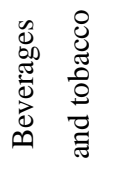 & 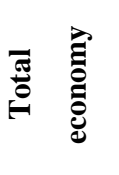 & 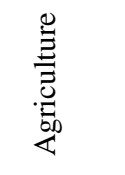 & 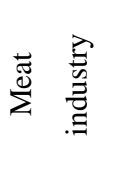 & 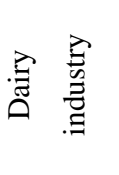 & 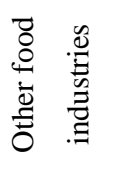 & 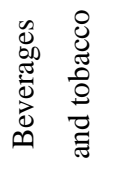 & 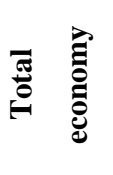 \\
\hline Andalusia & -1.28 & -25.23 & -31.68 & -24.11 & -29.39 & -13.75 & -0.62 & -10.93 & -19.57 & -10.91 & -9.65 & -5.48 & -0.76 & -16.87 & -24.65 & -16.01 & -18.59 & -8.95 \\
\hline Aragon & -5.68 & -32.10 & -27.54 & -32.47 & -52.53 & -18.89 & -3.97 & -16.85 & -19.25 & -19.86 & -54.42 & -9.88 & -4.49 & -23.22 & -22.41 & -24.07 & -51.99 & -13.62 \\
\hline Castile-La Mancha & -4.91 & -30.29 & -32.01 & -34.68 & -33.61 & -18.49 & -2.93 & -11.46 & -12.55 & -15.27 & -10.14 & -7.05 & -3.66 & -19.62 & -20.99 & -23.17 & -20.57 & -12.02 \\
\hline Asturias & -21.74 & -20.26 & -3.49 & -9.25 & 1.37 & -1.89 & -25.73 & -28.44 & -9.72 & -13.75 & -1.31 & -1.30 & -22.95 & -25.31 & -6.82 & -10.90 & 0.12 & -1.45 \\
\hline Balearic Islands & -2.51 & -37.41 & -43.98 & -32.02 & -37.87 & -12.17 & -1.46 & -24.10 & -31.90 & -14.22 & -25.73 & -5.31 & -1.76 & -30.01 & -37.27 & -21.83 & -30.87 & -8.33 \\
\hline Canary Islands & -1.45 & -19.12 & -12.84 & -22.48 & -8.45 & -3.64 & -0.86 & -10.30 & -5.11 & -7.63 & -4.96 & -0.67 & -1.04 & -14.52 & -8.78 & -14.44 & -6.43 & -1.98 \\
\hline Cantabria & -20.21 & -25.07 & N.A & -23.86 & N.A & -10.95 & -21.35 & -26.04 & N.A & -21.77 & N.A & -6.77 & -19.91 & -25.69 & N.A & -21.52 & N.A & -8.37 \\
\hline Castile and Leon & -5.21 & -21.97 & -33.95 & -29.51 & -32.16 & -17.51 & -2.26 & -8.05 & -18.83 & -12.08 & -13.91 & -6.66 & -3.43 & -13.86 & -25.24 & -19.07 & -21.87 & -11.28 \\
\hline Catalonia & -2.94 & -15.39 & -28.28 & -24.01 & -18.25 & -11.22 & -2.09 & -4.80 & -13.23 & -4.67 & -4.29 & -2.99 & -2.38 & -9.06 & -19.58 & -13.11 & -10.53 & -6.53 \\
\hline Galicia & -2.85 & -29.55 & -26.40 & -14.94 & -10.93 & -5.27 & -1.35 & -19.79 & -21.05 & -7.52 & -8.71 & -2.52 & -1.88 & -23.98 & -23.29 & -10.40 & -9.59 & -3.65 \\
\hline La Rioja & -4.04 & -42.31 & -46.39 & -34.17 & -39.06 & -11.56 & -1.67 & -20.42 & -28.90 & -7.62 & -12.90 & -3.38 & -2.57 & -30.68 & -36.92 & -19.84 & -24.74 & -6.99 \\
\hline Madrid & 1.10 & -12.48 & -16.87 & -18.11 & -9.15 & -11.39 & 1.19 & -0.95 & -3.57 & -1.35 & -4.59 & 0.64 & 1.28 & -5.66 & -9.00 & -8.48 & -6.49 & -4.77 \\
\hline Navarre & -6.71 & -40.44 & -49.28 & -30.42 & -37.80 & -19.14 & -3.91 & -27.17 & -44.27 & -13.02 & -25.95 & -9.54 & -4.98 & -32.85 & -46.14 & -20.21 & -31.05 & -13.64 \\
\hline Basque Country & -3.94 & -34.56 & -43.17 & -25.11 & -18.17 & -5.39 & -3.10 & -25.19 & -36.22 & -9.57 & -8.31 & -2.77 & -3.33 & -29.19 & -39.00 & -16.13 & -12.54 & -3.84 \\
\hline Extremadura & -1.86 & -40.54 & -43.57 & -32.25 & -37.72 & -10.06 & -0.99 & -23.26 & -29.74 & -11.86 & -12.45 & -4.39 & -1.17 & -30.63 & -35.64 & -20.25 & -24.18 & -6.71 \\
\hline Murcia & -2.10 & -28.26 & -27.07 & -29.06 & -23.85 & -10.36 & -16.42 & -24.38 & -23.66 & -16.70 & -15.54 & -16.29 & -7.84 & -23.75 & -22.94 & -20.13 & -18.15 & -11.71 \\
\hline Valencia & -1.97 & -34.10 & -30.80 & -30.31 & -24.64 & -11.80 & -1.97 & -18.72 & -10.63 & -6.67 & -9.08 & -4.81 & -1.84 & -25.04 & -19.61 & -17.19 & -15.92 & -7.88 \\
\hline Total & -3.26 & -23.31 & -30.10 & -26.89 & -30.70 & -13.87 & -3.17 & -10.10 & -16.99 & -11.01 & -13.83 & -5.99 & -2.89 & -15.54 & -22.40 & -17.35 & -21.17 & -9.25 \\
\hline
\end{tabular}

Note: N.A means data is not available. 
Table SI9. Sensitivity analysis of substitution between domestic commodities in the Spanish regions (lower values): regional and sector production results, $\sigma^{A 2}=0.1-3$ ( $\%$ change with respect to the baseline scenario)

\begin{tabular}{|c|c|c|c|c|c|c|c|c|c|c|c|c|c|c|c|c|c|c|c|c|c|}
\hline & \multicolumn{6}{|c|}{$\begin{array}{c}\text { Scenario } 1 \\
\text { (Taxes on production) }\end{array}$} & \multicolumn{9}{|c|}{$\begin{array}{c}\text { Scenario } 2 \\
\text { (Taxes on consumption) }\end{array}$} & \multicolumn{5}{|c|}{$\begin{array}{c}\text { Scenario } 3 \text { (Taxes on production and } \\
\text { consumption) }\end{array}$} & \multirow[b]{2}{*}{ 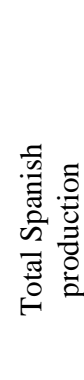 } \\
\hline & 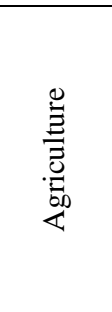 & 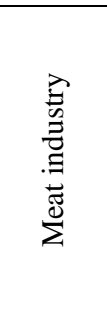 & 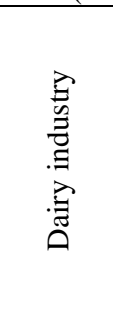 & 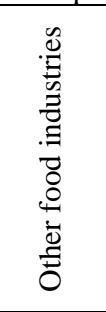 & 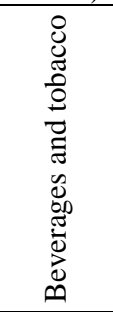 & 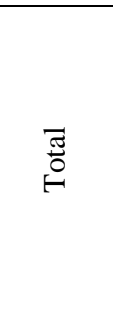 & 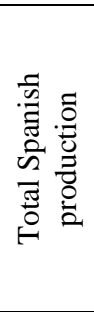 & 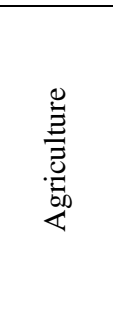 & 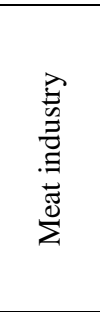 & 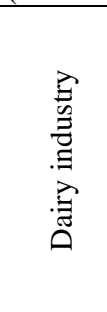 & 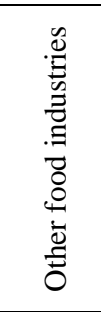 & $\begin{array}{l}8 \\
0 \\
0 \\
0 \\
0 \\
0 \\
0 \\
0 \\
0 \\
0 \\
0 \\
0 \\
0 \\
0 \\
0 \\
0\end{array}$ & $\stackrel{\pi}{0}$ & 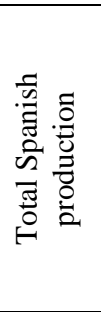 & 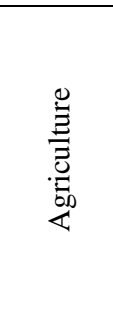 & 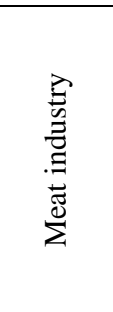 & 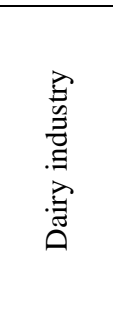 & 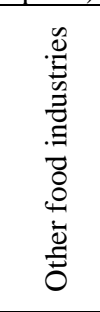 & 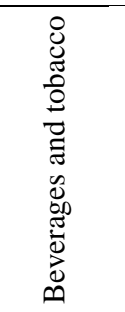 & $\stackrel{\pi}{0}$ & \\
\hline Andalusia & -3.00 & -7.50 & 17.35 & -2.18 & -9.10 & -3.51 & -1.16 & 6.41 & 10.24 & 20.61 & 12.37 & 3.50 & 8.50 & 0.22 & 1.62 & 0.80 & 16.77 & 4.89 & -2.88 & 2.26 & -0.47 \\
\hline Aragon & 2.31 & 5.30 & 13.73 & 21.13 & 333.34 & 18.88 & 1.50 & 8.87 & 19.24 & 18.52 & 29.02 & 207.90 & 22.18 & 1.89 & 5.20 & 11.10 & 14.18 & 24.16 & 251.82 & 19.09 & 1.58 \\
\hline Castile-La Mancha & -0.85 & -7.05 & -0.42 & 12.37 & -3.43 & -0.28 & -0.58 & 7.41 & 10.56 & 10.36 & 22.76 & 6.88 & 10.45 & 1.03 & 3.07 & 1.16 & 4.04 & 16.92 & 1.34 & 4.63 & 0.18 \\
\hline Asturias & 127.25 & 118.48 & 3.83 & 26.47 & -3.48 & 46.42 & 2.69 & 66.77 & 98.75 & 12.81 & 32.84 & 6.85 & 36.92 & 2.06 & 89.47 & 102.12 & 7.08 & 28.57 & 1.30 & 38.60 & 2.19 \\
\hline Balearic Islands & 68.93 & 43.25 & 59.38 & 5.19 & 60.80 & 47.23 & 0.94 & 39.75 & 45.90 & 44.85 & 17.63 & 45.22 & 36.66 & 0.71 & 50.14 & 41.62 & 46.89 & 10.98 & 49.11 & 38.84 & 0.74 \\
\hline Canary Islands & -6.25 & 29.99 & -4.82 & 4.35 & 2.35 & -0.24 & -0.97 & 4.91 & 36.58 & 7.83 & 17.03 & 10.33 & 10.38 & -0.48 & -0.57 & 30.95 & 0.89 & 10.28 & 5.63 & 4.69 & -0.70 \\
\hline Cantabria & 253.18 & 81.30 & 210.24 & 33.02 & 117.49 & 135.46 & 7.79 & 125.13 & 72.63 & 131.85 & 37.52 & 79.06 & 82.68 & 4.63 & 174.40 & 72.22 & 155.00 & 33.99 & 91.27 & 101.18 & 5.76 \\
\hline Castile and Leon & -1.01 & -12.26 & 13.73 & 0.69 & 10.92 & -1.05 & -0.84 & 7.33 & 6.90 & 18.53 & 14.42 & 15.44 & 10.61 & 0.96 & 2.96 & -3.03 & 14.18 & 7.26 & 12.01 & 4.30 & 0.02 \\
\hline Catalonia & 6.29 & -18.63 & 4.75 & -13.15 & -9.89 & -10.09 & -1.43 & 10.72 & 2.42 & 13.34 & 4.53 & 3.02 & 5.19 & -0.30 & 7.89 & -8.15 & 7.74 & -4.19 & -3.47 & -2.60 & -0.84 \\
\hline Galicia & 15.40 & 22.46 & 25.78 & -5.59 & 27.17 & 10.16 & 0.32 & 14.94 & 31.29 & 25.48 & 9.93 & 25.15 & 16.32 & 1.05 & 14.03 & 24.89 & 22.82 & 2.07 & 24.10 & 12.17 & 0.62 \\
\hline La Rioja & 64.07 & 22.31 & 45.28 & -2.39 & 8.06 & 20.69 & 2.83 & 37.49 & 31.19 & 36.72 & 12.22 & 13.73 & 20.70 & 2.93 & 46.85 & 24.77 & 36.79 & 4.72 & 9.88 & 19.02 & 2.63 \\
\hline Madrid & -6.25 & -19.28 & -10.97 & -14.11 & 12.84 & -9.18 & -1.12 & 4.91 & 1.96 & 4.28 & 3.84 & 16.59 & 6.01 & -0.96 & -0.57 & -8.68 & -3.52 & -4.98 & 13.44 & -1.79 & -1.02 \\
\hline Navarre & 37.63 & 38.18 & 113.82 & 0.19 & 56.22 & 24.27 & 2.06 & 25.24 & 42.34 & 76.24 & 14.06 & 42.48 & 25.61 & 2.27 & 29.02 & 37.54 & 85.90 & 6.85 & 45.70 & 23.17 & 2.02 \\
\hline Basque Country & 122.49 & 59.66 & 86.55 & -3.31 & 3.67 & 31.23 & 0.52 & 64.56 & 57.43 & 60.52 & 11.56 & 11.11 & 27.27 & 0.37 & 86.25 & 54.82 & 66.36 & 3.95 & 6.61 & 26.91 & 0.41 \\
\hline Extremadura & 6.92 & 27.60 & 47.17 & 4.65 & -0.44 & 7.42 & 0.61 & 11.01 & 34.90 & 37.81 & 17.25 & 8.67 & 14.53 & 1.73 & 8.31 & 29.03 & 38.14 & 10.54 & 3.56 & 10.23 & 1.08 \\
\hline Murcia & -6.25 & -0.91 & 4.10 & -2.03 & -6.13 & -4.75 & -1.61 & 4.91 & 14.87 & 12.97 & 12.47 & 5.27 & 7.35 & 0.82 & -0.57 & 6.10 & 7.28 & 5.01 & -0.68 & 1.21 & -0.39 \\
\hline Valencia & -6.25 & 7.58 & -1.10 & -10.82 & 4.34 & -4.43 & -0.99 & 4.91 & 20.84 & 9.97 & 6.20 & 11.52 & 8.33 & 0.11 & -0.57 & 12.93 & 3.55 & -2.25 & 7.12 & 1.68 & -0.42 \\
\hline Total for Spain & 8.94 & -4.34 & 14.30 & -3.27 & 4.87 & 3.11 & -0.47 & 12.04 & 13.42 & 5.95 & 8.90 & 11.02 & 12.41 & 0.28 & 9.67 & 3.34 & 14.58 & 3.99 & 7.50 & 7.08 & -0.12 \\
\hline
\end{tabular}


Table SI10. Sensitivity analysis of substitution between domestic commodities in the Spanish regions (higher values): regional and sector production results, $\sigma^{A 2}=0.1-6(\%$ change with respect to the baseline scenario)

\begin{tabular}{|c|c|c|c|c|c|c|c|c|c|c|c|c|c|c|c|c|c|c|c|c|c|}
\hline & \multicolumn{7}{|c|}{$\begin{array}{c}\text { Scenario 1 } \\
\text { (Taxes on production) }\end{array}$} & \multicolumn{7}{|c|}{$\begin{array}{c}\text { Scenario } 2 \\
\text { (Taxes on consumption) }\end{array}$} & \multicolumn{6}{|c|}{ Scenario 3 (Taxes on production and consumption) } & \multirow[b]{2}{*}{ 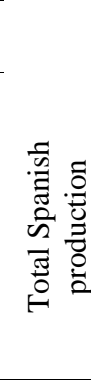 } \\
\hline & 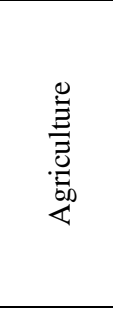 & 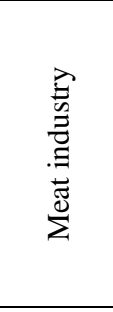 & 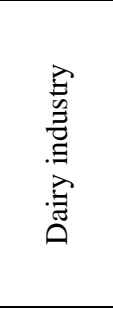 & 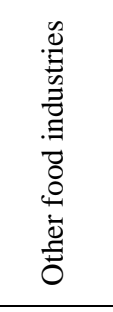 & 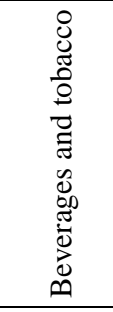 & 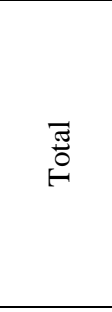 & 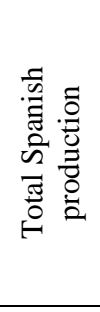 & 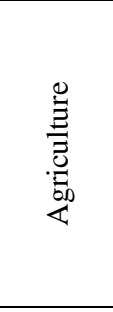 & 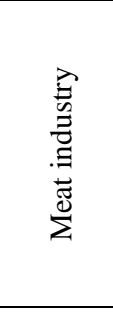 & 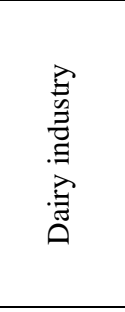 & 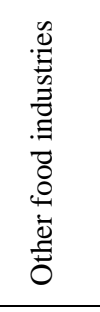 & 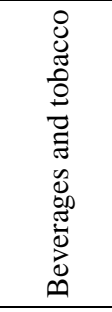 & $\stackrel{\pi}{0}$ & 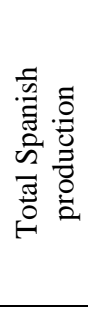 & $\frac{\stackrel{0}{\Xi}}{\stackrel{0}{\Xi}}$ & 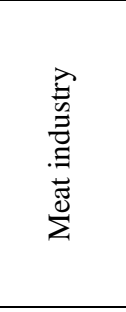 & 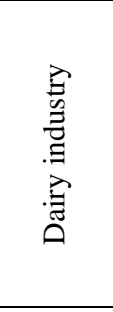 & 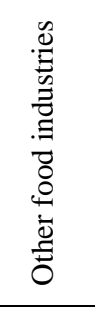 & 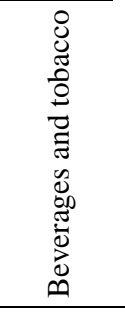 & 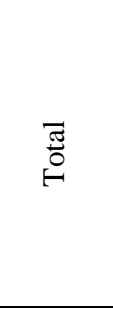 & \\
\hline Andalusia & -5.47 & -3.22 & 34.42 & -0.51 & -10.04 & -3.26 & -1.10 & 7.48 & 13.28 & 29.05 & 14.81 & 4.46 & 10.37 & 0.30 & 1.06 & 3.79 & 28.65 & 6.49 & -3.13 & 3.12 & -0.42 \\
\hline Aragon & 1.04 & 15.23 & 28.87 & 29.77 & 472.60 & 28.09 & 2.62 & 10.43 & 24.71 & 26.15 & 34.36 & 267.63 & 27.80 & 2.48 & 5.49 & 17.95 & 24.75 & 30.56 & 346.85 & 26.08 & 2.39 \\
\hline Castile-La Mancha & -2.83 & -2.57 & 7.17 & 18.39 & -2.05 & 1.79 & -0.16 & 8.67 & 13.68 & 14.79 & 27.01 & 8.82 & 12.97 & 1.33 & 2.86 & 4.29 & 9.52 & 21.51 & 2.66 & 6.65 & 0.49 \\
\hline Asturias & 154.10 & 178.27 & 13.69 & 36.71 & -2.13 & 64.64 & 4.08 & 79.85 & 125.81 & 18.20 & 38.84 & 8.78 & 46.10 & 2.60 & 109.54 & 143.10 & 14.09 & 36.07 & 2.61 & 51.68 & 3.10 \\
\hline Balearic Islands & 82.66 & 69.90 & 98.90 & 9.06 & 88.47 & 64.88 & 1.72 & 47.45 & 58.61 & 62.80 & 20.99 & 58.18 & 45.74 & 0.98 & 60.97 & 59.91 & 73.92 & 14.10 & 68.31 & 51.59 & 1.23 \\
\hline Canary Islands & -9.44 & 50.80 & 0.43 & 7.97 & 6.09 & 1.65 & -0.82 & 5.67 & 46.77 & 11.26 & 20.28 & 13.26 & 12.87 & -0.53 & -1.64 & 45.25 & 4.78 & 13.23 & 8.57 & 6.62 & -0.67 \\
\hline Cantabria & 308.37 & 124.71 & 330.29 & 45.22 & 168.38 & 177.00 & 10.44 & 149.83 & 92.60 & 183.88 & 44.33 & 101.75 & 101.73 & 5.75 & 214.41 & 101.99 & 236.37 & 42.83 & 126.25 & 130.55 & 7.58 \\
\hline Castile and Leon & -3.03 & -10.07 & 28.88 & 3.22 & 18.17 & 1.29 & -0.42 & 8.58 & 9.03 & 26.15 & 17.21 & 19.85 & 13.26 & 1.29 & 2.72 & -1.47 & 24.76 & 9.45 & 17.33 & 6.47 & 0.35 \\
\hline Catalonia & 5.92 & -19.25 & 15.10 & -14.77 & -11.16 & -10.54 & -1.25 & 12.64 & 3.33 & 18.94 & 5.60 & 3.85 & 6.56 & -0.21 & 8.81 & -8.52 & 15.08 & -4.84 & -3.94 & -2.46 & -0.74 \\
\hline Galicia & 17.08 & 39.94 & 47.36 & -4.95 & 41.08 & 15.76 & 0.95 & 17.70 & 40.04 & 35.83 & 11.95 & 32.34 & 20.43 & 1.40 & 16.39 & 36.92 & 37.74 & 2.97 & 33.94 & 16.67 & 1.07 \\
\hline La Rioja & 76.69 & 39.73 & 77.27 & -0.78 & 14.14 & 28.86 & 4.29 & 44.74 & 39.91 & 51.47 & 14.64 & 17.65 & 25.72 & 3.72 & 56.92 & 36.76 & 58.73 & 6.28 & 14.40 & 25.22 & 3.68 \\
\hline Madrid & -9.44 & -20.19 & -9.01 & -16.01 & 20.88 & -8.55 & -0.89 & 5.67 & 2.75 & 6.33 & 4.80 & 21.32 & 7.78 & -1.04 & -1.64 & -9.24 & -1.84 & -5.82 & 19.29 & -0.99 & -0.96 \\
\hline Navarre & 44.31 & 62.59 & 182.40 & 2.57 & 82.02 & 35.11 & 3.35 & 30.05 & 54.08 & 106.49 & 16.80 & 54.66 & 31.88 & 2.94 & 34.90 & 54.31 & 132.54 & 8.94 & 63.63 & 31.17 & 2.94 \\
\hline Basque Country & 148.26 & 93.54 & 140.56 & -1.98 & 7.95 & 43.93 & 1.05 & 77.20 & 73.27 & 84.60 & 13.86 & 14.27 & 34.22 & 0.50 & 105.57 & 78.06 & 103.17 & 5.33 & 9.92 & 36.16 & 0.72 \\
\hline Extremadura & 6.69 & 47.34 & 80.16 & 8.37 & 2.17 & 10.66 & 1.18 & 12.99 & 44.63 & 52.99 & 20.54 & 11.12 & 17.72 & 2.09 & 9.32 & 42.60 & 60.77 & 13.55 & 5.72 & 13.22 & 1.50 \\
\hline Murcia & -9.44 & 6.28 & 14.11 & -0.32 & -5.86 & -5.61 & -1.78 & 5.67 & 19.16 & 18.42 & 14.93 & 6.74 & 8.87 & 0.94 & -1.64 & 11.08 & 14.39 & 6.64 & -0.10 & 1.44 & -0.43 \\
\hline Valencia & -9.44 & 18.51 & 6.13 & -11.73 & 8.90 & -3.47 & -0.77 & 5.67 & 26.75 & 14.24 & 7.57 & 14.79 & 10.46 & 0.26 & -1.64 & 20.47 & 8.79 & -2.42 & 10.61 & 2.95 & -0.26 \\
\hline Total for Spain & 9.16 & 1.34 & 29.74 & -1.92 & 9.64 & 6.28 & -0.09 & 12.04 & 13.42 & 5.95 & 8.90 & 11.02 & 15.43 & 0.44 & 11.01 & 7.29 & 25.37 & 5.37 & 11.14 & 9.85 & 0.12 \\
\hline
\end{tabular}


Table SI11. Sensitivity analysis of alternative water scarcity indexes (instead of Table 6)

\begin{tabular}{|c|c|c|c|c|c|c|c|c|c|c|c|c|}
\hline \multirow[b]{3}{*}{ Region } & \multicolumn{6}{|c|}{$\begin{array}{l}\text { Index a. Blue and green water consumption in relation to } \\
\text { water availability }\end{array}$} & \multicolumn{6}{|c|}{$\begin{array}{l}\text { Index b. Potential water availability considering water } \\
\text { transfers, reutilization and desalination capabilities and } \\
\text { environmental reserves }\end{array}$} \\
\hline & \multicolumn{2}{|c|}{ Scenario 1} & \multicolumn{2}{|c|}{ Scenario 2} & \multicolumn{2}{|c|}{ Scenario 3} & \multicolumn{2}{|c|}{ Scenario 1} & \multicolumn{2}{|c|}{ Scenario 2} & \multicolumn{2}{|c|}{ Scenario 3} \\
\hline & Level & $\begin{array}{c}\% \\
\text { change }\end{array}$ & Level & $\begin{array}{c}\% \\
\text { change }\end{array}$ & Level & $\begin{array}{c}\% \\
\text { change }\end{array}$ & Level & $\begin{array}{c}\% \\
\text { change }\end{array}$ & Level & $\begin{array}{c}\% \\
\text { change }\end{array}$ & Level & $\begin{array}{c}\% \\
\text { change }\end{array}$ \\
\hline Andalusia & 231.32 & -1.16 & 234.89 & 0.36 & 233.12 & -0.39 & 48.04 & -1.16 & 48.74 & 0.29 & 48.39 & -0.44 \\
\hline Aragon & 135.85 & 1.95 & 136.94 & 2.77 & 136.53 & 2.46 & 60.10 & 1.80 & 60.42 & 2.34 & 60.24 & 2.04 \\
\hline Castile-La Mancha & 198.13 & -0.48 & 202.15 & 1.54 & 200.22 & 0.57 & 38.98 & -0.52 & 39.69 & 1.28 & 39.33 & 0.36 \\
\hline Asturias & 9.18 & 3.17 & 9.16 & 2.98 & 9.18 & 3.19 & 2.86 & 2.95 & 2.85 & 2.49 & 2.85 & 2.66 \\
\hline Balearic Islands & 160.47 & 1.23 & 160.25 & 1.10 & 160.44 & 1.21 & 40.71 & 1.13 & 40.61 & 0.89 & 40.64 & 0.97 \\
\hline Canary Islands & 218.93 & -0.91 & 219.61 & -0.60 & 219.26 & -0.75 & 73.16 & -0.88 & 73.42 & -0.54 & 73.30 & -0.70 \\
\hline Cantabria & 12.41 & 8.71 & 12.17 & 6.56 & 12.32 & 7.87 & 6.40 & 8.16 & 6.24 & 5.49 & 6.31 & 6.67 \\
\hline Castile and Leon & 110.12 & -0.71 & 112.50 & 1.44 & 111.34 & 0.39 & 26.18 & -0.76 & 26.70 & 1.21 & 26.43 & 0.20 \\
\hline Catalonia & 132.76 & -1.36 & 134.21 & -0.28 & 133.46 & -0.84 & 59.39 & -1.35 & 60.04 & -0.26 & 59.71 & -0.81 \\
\hline Galicia & 16.57 & 0.55 & 16.74 & 1.58 & 16.66 & 1.11 & 1.42 & 0.45 & 1.43 & 1.31 & 1.43 & 0.86 \\
\hline La Rioja & 130.30 & 3.24 & 131.58 & 4.26 & 131.10 & 3.88 & 24.27 & 2.97 & 24.40 & 3.53 & 24.31 & 3.16 \\
\hline Madrid & 201.58 & -1.00 & 201.33 & -1.13 & 201.44 & -1.07 & 197.02 & -0.99 & 196.92 & -1.04 & 196.98 & -1.01 \\
\hline Navarre & 60.49 & 2.55 & 60.93 & 3.30 & 60.78 & 3.04 & 24.39 & 2.35 & 24.49 & 2.79 & 24.43 & 2.53 \\
\hline Basque country & 20.64 & 0.72 & 20.61 & 0.57 & 20.63 & 0.68 & 10.80 & 0.67 & 10.77 & 0.46 & 10.78 & 0.56 \\
\hline Extremadura & 110.56 & 0.78 & 112.39 & 2.45 & 111.56 & 1.69 & 40.22 & 0.66 & 40.78 & 2.06 & 40.49 & 1.34 \\
\hline Murcia & 443.58 & -1.71 & 456.65 & 1.19 & 450.24 & -0.23 & 225.18 & -1.71 & 231.36 & 0.99 & 228.30 & -0.35 \\
\hline Valencian community & 150.10 & -0.89 & 151.83 & 0.25 & 150.97 & -0.32 & 103.39 & -0.89 & 104.53 & 0.20 & 103.97 & -0.34 \\
\hline Total & 95.96 & -0.33 & 96.76 & 0.50 & 96.38 & 0.11 & 30.47 & -0.37 & 30.70 & 0.39 & 30.58 & 0.00 \\
\hline
\end{tabular}




\section{References}

De Melo, J. and D. Tarr (1992) A general equilibrium analysis of US foreign trade policy. The MIT Press. Cambridge, MA.

De Schoutheete, D. (2012) Control of Carbon Emissions and Energy Fiscal Reform in Spain. A Computable General Equilibrium Assessment. Universitat Autònoma de Barcelona, Barcelona

Gómez, C.M., D. Tirado and J. Rey-Maquieira (2004) Water exchanges versus water works: Insights from a computable general equilibrium model for the Balearic Islands. Water Resources Research, $40,1-11$.

Hertel, T.W. (1997) Global Trade Analysis: Modeling and Applications. Cambridge University Press, Cambridge.

Jomini, P., J.F. Zeitsch, R. McDougall, A. Welsh, S. Brown, J. Hambley and J. Kelly (1991) SALTER: A General Equilibirum Model of the World Economy. Industry Commission, Canberra

Mainar, A. (2010) Consumption Patterns and Environmental Impacts of the CO2, Emissions: An Approximation from Input-Output Analysis. University of Zaragoza, Zaragoza.

MAPAMA (2005) Yearbook of Agricultural Statistic., Ministry of Agricululture, Food and Environment, Madrid, Spain.

NSI (2005) Unemployment rate., National Institute of Statistics, Madrid, Spain.

Seung, C.K., T.R. Harris, T.R. McDiarmid and W.D. Shaw (1998) Economics impacts of water reallocation: a CGE analysis for the Walker River Basin of Nevada and California. Journal of Regional Analysis and Policy, 28, 13-34.

Tsigas, M.E. (1997) A Modeling Framework for Multi-regional Analysis of the US Economy. US Department of Agriculture, Economic Research Service, Food and Rural Economics Division, Washington D.C. 